Doc.20050222.0008

QA: QA

ANL-WIS-MD-000021 REV 03

February 2005

NOTICE OF OPEN CHANGE DOCUMENTS - THIS DOCUMENT IS IMPACTED BY THE LISTED CHANGE DOCUMENT AND CANNOT BE USED WITHOUT IT.

1) ACN-001, DATED 08/12/2005

\title{
Cladding Degradation Summary for LA
}

Prepared for:

U.S. Department of Energy

Office of Civilian Radioactive Waste Management

Office of Repository Development

1551 Hillshire Drive

Las Vegas, Nevada 89134-6321

Prepared by:

Bechtel SAIC Company, LLC

1180 Town Center Drive

Las Vegas, Nevada 89144

Under Contract Number

DE-AC28-01RW12101 


\section{DISCLAIMER}

This report was prepared as an account of work sponsored by an agency of the United States Government. Neither the United States Government nor any agency thereof, nor any of their employees, nor any of their contractors, subcontractors or their employees, makes any warranty, express or implied, or assumes any legal liability or responsibility for the accuracy, completeness, or any third party's use or the results of such use of any information, apparatus, product, or process disclosed, or represents that its use would not infringe privately owned rights. Reference herein to any specific commercial product, process, or service by trade name, trademark, manufacturer, or otherwise, does not necessarily constitute or imply its endorsement, recommendation, or favoring by the United States Government or any agency thereof or its contractors or subcontractors. The views and opinions of authors expressed herein do not necessarily state or reflect those of the United States Government or any agency thereof. 


\section{OCRWM}

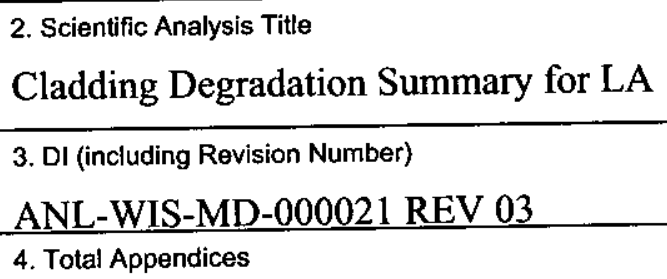

\begin{tabular}{|c|c|}
\hline 12. Revision No. & 13. Description of Change \\
\hline 00 & Initial Issue. \\
\hline 01 & $\begin{array}{l}\text { Complete revision to address changes due to regulatory integration. Change bars were } \\
\text { not used because the changes were too extensive to track. }\end{array}$ \\
\hline 02 & $\begin{array}{l}\text { Minor revision to clarify validation terminology. This-revision REVISION NEVER issuED. MrO } \\
\text { completion. THIS DOCUMENT WAS NEVR }\end{array}$ \\
\hline 03 & $\begin{array}{l}\text { Revision to change document from a model report to an analysis report. This revision } \\
\text { responds to the concerns documented in CR } 99 \text {. CR } 4917 \text { was written to address an } \\
\text { issue in this document; however, the condition description was incorrect. CR } 4917 \text { will } \\
\text { be closed to CR } 4937 \text {, which is resolved with the issuance of Rev } 03 \text { of this document. }\end{array}$ \\
\hline & \\
\hline & \\
\hline
\end{tabular}




\section{ACKNOWLEDGEMENTS}

This analysis report was developed through the contributions of the following individuals, listed in alphabetical order:

- Eric Siegmann, AREVA. Originator and lead author of the initial version of the subject report, including the development of the original model and model abstraction.

- David Stahl, AREVA. Originator and lead author for REV 01, Rev 02 and REV 03 of this report. Responsible for incorporation of Regulatory Integration Team comments, including the development of qualified sources, the enhancement of assumptions and discussion, and the conversion of this report to an analysis. 


\section{EXECUTIVE SUMMARY}

The purpose of this analysis report is to develop the summary cladding degradation abstraction that will be used in the Total System Performance Assessment for the License Application (TSPA-LA). Most civilian commercial nuclear fuel is encased in Zircaloy cladding. The analysis addressed in this report is intended to describe the postulated condition of commercial Zircaloy-clad fuel as a function of postclosure time after it is placed in the repository. Earlier total system performance assessments analyzed the waste form as exposed $\mathrm{UO}_{2}$, which was available for degradation at the intrinsic dissolution rate. Water in the waste package quickly became saturated with many of the radionuclides, limiting their release rate. In the total system performance assessments for the Viability Assessment and the Site Recommendation, cladding was analyzed as part of the waste form, limiting the amount of fuel available at any time for degradation.

The current analysis is divided into two stages. The first considers predisposal rod failures (most of which occur during reactor operation and associated activities) and postdisposal mechanical failure (from static loading of rocks) as mechanisms for perforating the cladding. Other fuel failure mechanisms including those caused by handling or transportation have been screened out (excluded) or are treated elsewhere. All stainless-steel-clad fuel, which makes up a small percentage of the overall amount of fuel to be stored, is taken as failed upon placement in the waste packages. The second stage of the degradation analysis is the splitting of the cladding from the reaction of water or moist air and $\mathrm{UO}_{2}$ or from internal cladding reaction. The splitting has been observed to be rapid in comparison to the total system performance assessment time steps and is taken to be instantaneous. After the cladding splits, the rind buildup inside the cladding widens the split, increasing the diffusion area from the fuel rind to the waste package interior.

This analysis report summarizes its components, developed for the two stages noted above, that are used as inputs to TSPA-LA. The analysis concludes that less than $2 \%$ of the fuel, including all of the stainless-steel clad fuel, received at the repository is failed (perforated) upon receipt at the repository. All failed fuel is assumed to axially split upon waste package failure exposing the fuel to oxidation from the in-package environment. TSPA-LA then calculates the release of radionuclides from the exposed volume of oxidized fuel. 


\section{INTENTIONALLY LEFT BLANK}




\section{CONTENTS}

Page

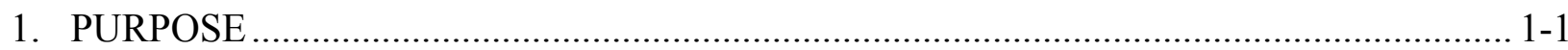

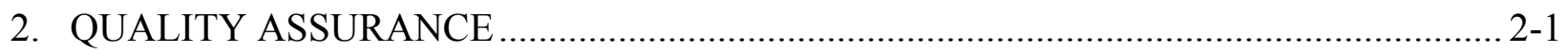

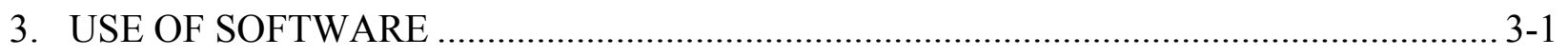

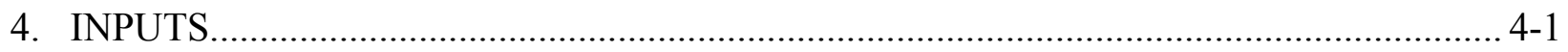

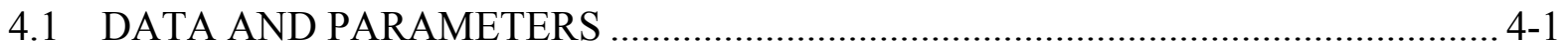

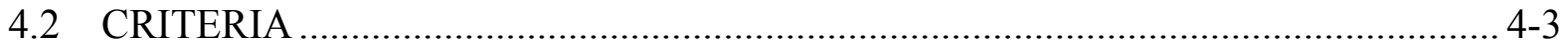

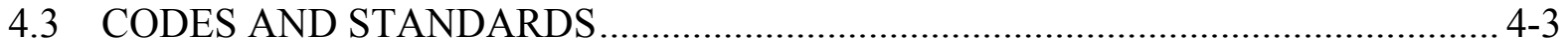

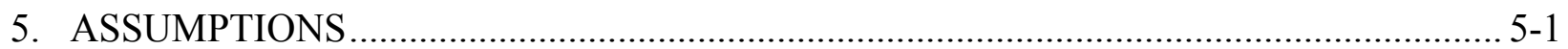

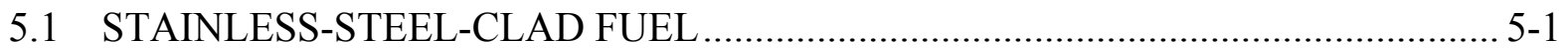

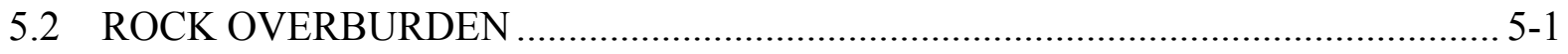

5.3 INSTANT SPLITTING ……………………….......................................... 5-2

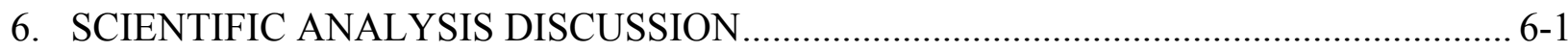

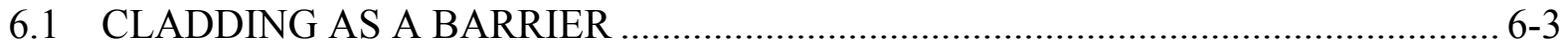

6.1.1 Barrier Capability................................................................................ 6-4

6.1.2 Barrier Time Period of Function................................................................ 6-4

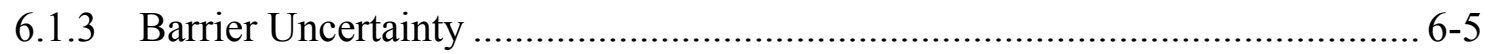

6.1.4 Barrier Consistency with TSPA............................................................... 6-5

6.2 COMMERCIAL FUEL ROD CLADDING DEGRADATION ABSTRACTION

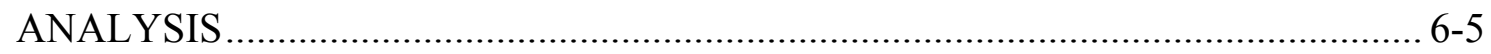

6.2.1 Cladding Condition As-Received ................................................................. 6-6

6.2.2 Stainless Steel Cladding Distribution ......................................................... 6-7

6.2.3 Mechanical Failure of Cladding............................................................... 6-9

6.2.5 Localized Corrosion Degradation .................................................................. 6-14

6.3 ALTERNATIVE SCIENTIFIC APPROACHES ................................................ 6-14

6.3.1 Cladding Condition As-Received ............................................................... 6-15

6.3.2 Stainless Steel Cladding Distribution ........................................................ 6-15

6.3.3 Mechanical Failure of Cladding................................................................ 6-16

6.3.4 Split Cladding ………………………………...................................... 6-16

6.3.5 Summary of Alternative Scientific Approach Considerations......................... 6-16

6.4 FEATURES, EVENTS, AND PROCESSES ADDRESSED ………........................ 6-17

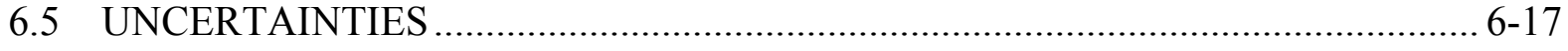

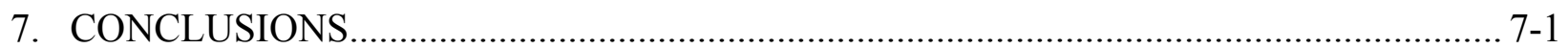

7.1 OUTPUT TO THE TSPA-LA MODEL ………….................................................

7.1.1 Cladding Condition As-Received .......................................................... 7-2

7.1.2 Stainless Steel Cladding Distribution …………............................................ 7-2

7.1.3 Mechanical Failure of Cladding ................................................................ 7-2

7.1.4 Split Cladding ……………............................................................... 7-2

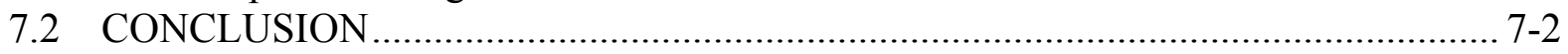




\section{CONTENTS (Continued)}

Page

7.3 YUCCA MOUNTAIN REVIEW PLAN ACCEPTANCE CRITERIA ………............ 7-3

7.3.1 Barriers (Section 2.2.1.1.3) .......................................................................

7.3.2 Barrier Degradation (Section 2.2.1.3.1.3) ...................................................... 7-3

7.3.3 Mechanical Disruption of Engineered Barriers (Section 2.2.1.3.2.3).............. 7-5

7.3.4 Radionuclide Release Rates And Solubility Limits (Section 2.2.1.3.4.3) ........ 7-6

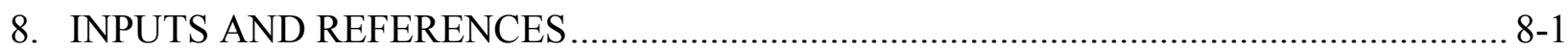

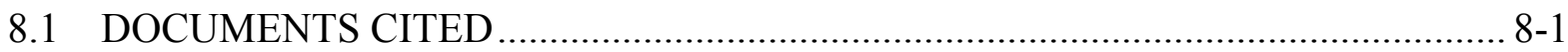

8.2 CODES, STANDARDS, REGULATIONS AND PROCEDURES …………............. 8-5

8.3 SOURCE DATA, LISTED BY DATA TRACKING NUMBER ………………......... 8-6

8.4 OUTPUT DATA, LISTED BY DATA TRACKING NUMBER .............................. 8-6

\section{TABLES}

Page

4-1. Input Values to Clad Degradation Analysis.............................................................. 4-2

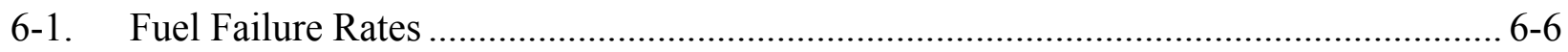

6-2. Comparison of Fuel Reliability from Various Sources................................................. 6-7

6-3. Input Variables to Calculate Cladding Split Geometry ............................................... 6-12

6-4. Calculated Variables and Equations to Calculate Cladding Split Geometry .................. 6-13

6-5. Alternative Scientific Approaches Considered ...................................................... 6-17

6-6. Included FEPs for this Analysis Report................................................................... 6-17

7-1. Summary of Cladding Degradation Values to be Used in the TSPA-LA Model ............. 7-1 


\section{ACRONYMS}

ANL

ASTM

BWR

CSNF

DOE

DTN

EPRI

FEPs

LWR

NRC

PWR

SNF

TER

TIC

TSPA

TSPA-LA

TSPA-SR
Argonne National Laboratory

American Society for Testing and Materials

boiling water reactor

Commercial Spent Nuclear Fuel

U.S. Department of Energy

data tracking number

Electric Power Research Institute

features, events, and processes

light water reactor

U.S. Nuclear Regulatory Commission

pressurized water reactor

spent nuclear fuel

Technical Error Report

Technical Information Center

total system performance assessment

Total System Performance Assessment for the License Application

Total System Performance Assessment for the Site Recommendation 


\section{INTENTIONALLY LEFT BLANK}




\section{PURPOSE}

The purpose of this analysis report is to develop the summary of cladding degradation to be used in the Total System Performance Assessment for the License Application (TSPA-LA). The scope of this analysis is to evaluate commercial spent nuclear fuel (CSNF) cladding under the TSPA-LA repository design. This document was prepared in accordance with the Technical Work Plan for Postclosure Waste Form Modeling (BSC 2005 [DIRS 172622]).

Most civilian commercial nuclear fuel is encased in Zircaloy cladding. Zircaloy is high-purity zirconium alloyed with tin with small additions of nickel and chromium, with and without small additions of iron. The term "Zircaloy" is also inclusive of newer alloys that have a lower tin content or have small additions of niobium. The analysis has been developed to describe cladding degradation from the expected failure modes. These modes include failure before receipt at the repository (due to reactor operation impacts, during spent fuel storage in pool and dry storage, and handling) and degradation in the repository (mechanical failure). It is expected that unfailed (not breached or perforated) Zircaloy cladding will remain intact for at least 10,000 years, the prescribed regulatory period. For those fuel rods that are assumed to breach, the cladding is conservatively taken to be axially split open due to strain induced by fuel oxidation and swelling or by growth of the oxide layer on the inside of the cladding. This does not occur until the waste package is breached. Stainless-steel-clad fuel is also addressed in this analysis report. However, all stainless steel cladding is assumed to be failed prior to emplacement.

There are constraints, caveats, and limitations to this cladding degradation analysis. This analysis is based on commercial water reactor fuel with Zircaloy cladding. The analysis discussed herein does not apply to fuel from a commercial gas cooled reactor (Fort St. Vrain), which is included in the inventory of U.S. Department of Energy (DOE) fuels. DOE fuels are not addressed in this report. Naval Nuclear Propulsion Program cladding/SNF performance is discussed in Naval Nuclear Propulsion Program Technical Support Document for the License Application, which is a classified document.

Commercial spent nuclear fuel reliability from reactor operation is determined for both pressurized water reactors (PWRs) and boiling water reactors (BWRs). This analysis is also limited to fuel exposed to normal operation and anticipated operational occurrences (i.e., events that are anticipated to occur within a reactor lifetime) and is not applicable to fuel that has been exposed to severe accidents. It is also limited to a repository design in which the fuel rod temperature is always less than $350^{\circ} \mathrm{C}$ during postclosure. Fuel burnup projections have been limited to the current commercial reactor licensing environment that restricts fuel enrichment, oxide coating thickness, and rod plenum pressures. Input uncertainties are discussed in Sections 4.1 and 6, while uncertainties are summarized in Section 6.5. The information provided in this analysis will be used in evaluating the postclosure performance of the repository in relation to waste form degradation.

This analysis report complements the work reported in Clad Degradation - Summary and Abstraction (CRWMS M\&O 2001 [DIRS 151662]), including additional corroboration of the cladding degradation analyses. This referenced report contains the cladding abstraction used in the Total System Performance Assessment for the Site Recommendation (TSPA-SR) model. Clad Degradation - Summary and Abstraction (CRWMS M\&O 2001 [DIRS 151662]) is not 
being superseded or revised because it contains a statistical creep analysis that is referenced for excluded FEPs. 


\section{QUALITY ASSURANCE}

The Quality Assurance program applies to the development of this document because this analysis will be part of the TSPA-LA safety analysis. This document was prepared in accordance with Technical Work Plan forPost Closure Waste Form Modeling (BSC 2005 [DIRS 172622]), which directs the work identified in work package ARTM03. The technical work plan was prepared in accordance with LP-2.29Q-BSC, Planning for Science Activities. All input data for the document are identified and tracked in accordance with LP-3.15Q-BSC, Managing Technical Product Inputs. This report indirectly impacts structures, systems, or components classified in accordance with AP-2.22Q, Classification Criteria and Maintenance of the Monitored Geologic Repository Q-List as Safety Category (SC) in the Q-List (BSC 2004 [DIRS 168361]). The technical work plan contains the Process Control Evaluation used to evaluate the control of electronic management of data (BSC 2005 [DIRS 172622], Appendix A) during analysis and documentation activities. This evaluation determined that the methods identified in the implementing procedures are adequate. Data submittal was consistent with AP-SIII.3Q, Submittal and Incorporation of Data to the Technical Data Management System. No deviations from these methods were performed. As directed in the technical work plan, this document was prepared in accordance with LP-SIII.9Q-BSC, Scientific Analysis, and reviewed in accordance with LP-2.14Q-BSC, Document Review. 


\section{INTENTIONALLY LEFT BLANK}




\section{USE OF SOFTWARE}

No software is used in this analysis report. This analysis report was documented using only commercially available software (Microsoft Word 97, SR2) for word processing, which is exempt from qualification requirements in accordance with LP-SI.11Q-BSC, Software Management. There were no additional applications (routines or macros) developed for documentation using this commercial software. 


\section{INTENTIONALLY LEFT BLANK}




\section{INPUTS}

\subsection{DATA AND PARAMETERS}

The project data is presented by data tracking number (DTN) or accession number, while nonproject technical information is presented by Technical Information Center (TIC) catalog numbers in this section. Both data and technical information are summarized in Table 4-1.

1. TIC: 242976 (Roberts et al. 1990 [DIRS 107105], pp. 766 to 767)

The density of schoepite (Table 4-1, Item 1) is used in Section 6.2.4 to calculate the split geometry as the pellet corrodes. The split geometry is directly related to the change in volume from unreacted $\mathrm{UO}_{2}$ to schoepite. This source is the Encyclopedia of Minerals and values used are Established Fact.

2. DTN: LL010902212241.026 [DIRS 163089]

The porosity of schoepite (Table 4-1, Item 2) is used in Section 6.2.4 to calculate the split geometry as the pellet corrodes. The three values of porosity for the schoepite rind $(0.05,0.15$, and 0.30$)$ represent schoepite exposed to two different flow rates of water and the presence of water vapor.

3. TIC: 243741 (Lide and Frederikse 1997 [DIRS 103178], pp. 4-14 to 4-31)

The molecular weight of schoepite (Table 4-1, Item 3), summed from the individual molecular weights, is used in Section 6.2.4 to calculate the split geometry as the pellet corrodes. This source is CRC Handbook of Chemistry and Physics and values used are Established Fact.

4. TIC: 243741 (Lide and Frederikse 1997 [DIRS 103178], p. 4-94)

The theoretical density and molecular weight of $\mathrm{UO}_{2}$ (Table 4-1, Item 4) is used in Section 6.2.4 to calculate the split geometry as the pellet corrodes. This source is CRC Handbook of Chemistry and Physics and values used are Established Fact.

5. TIC: 245486 (Preble et al. 1993 [DIRS 107407]).

The fuel pellet diameter, number of rods in an assembly, and active rod length for a typical (Westinghouse) $17 \times 17$ PWR assembly (Table A.1 of the reference) is used in Section 6.2.4 to calculate the cladding split geometry as the pellet corrodes. This data source was used because the majority of the SNF proposed for inclusion in the Yucca Mountain Repository will come from this type of PWR. Thus, this source contains the relevant information needed for this evaluation. This input source is qualified for its intended use within this technical product (report) per LP-SIII.9Q-BSC, Section 5.2.1(k), as corroborating data are available. The same information (e.g., pellet diameter, rods per assembly, and active fuel rod length) is found in a report by Roddy et al. (1985 [DIRS 120630]), 
which was independently developed by Oak Ridge National Laboratory using database information acquired directly from fuel rod manufacturers.

6. TIC: 246541 (S. Cohen \& Associates 1999 [DIRS 135910], p. 6-11, Table 6.2, p. $7-1)$

S. Cohen \& Associates performed a study of the effectiveness of fuel rod cladding as an engineered barrier in the repository. The U.S. Environmental Protection Agency (EPA) sponsored this study. As part of the study, S. Cohen \& Associates evaluated as-received SNF cladding failures. Failures from reactor operation, pool storage, dry storage, rod consolidation, and other handling failures were reviewed (S. Cohen \& Associates 1999 [DIRS 135910], p. 7-1). Because the SNF that is proposed for the Yucca Mountain Repository will have come from similar reactors and will have been treated to the same storage processes, the data from this investigation are directly applicable as TSPA-LA input. The authors conclude that the expected value of the parameter for failed fuel, as-received, is $0.1 \%$ with the range being $0.01 \%$ to $1 \%$, based on historical data (S. Cohen \& Associates 1999 [DIRS 135910], p. 6-11, Table 6.2).

The investigators in these studies are recognized national experts in the field and the U.S. The EPA contracted for these data to support their efforts to develop 40 CFR 197 regulations specifically for the Yucca Mountain Repository. This technical information is appropriate for use in this analysis report because it is an independent evaluation of as-received fuel failures. Thus, the data are considered qualified for use within this technical product based upon LP-SIII.9Q-BSC, Section 5.2.1(k), specifically in regard to the qualifications of the personnel and organization generating the data.

Table 4-1. Input Values to Clad Degradation Analysis

\begin{tabular}{|c|c|c|c|}
\hline Item & Input name & Source and Location & Value \\
\hline 1 & $\begin{array}{l}\text { Theoretical Density of } \\
\text { Schoepite }\end{array}$ & $\begin{array}{l}\text { Roberts et al. } 1990 \text { [DIRS 107105] } \\
\text { Schoepite properties }\end{array}$ & 4.83 (calculated) $\mathrm{g} / \mathrm{cm}^{3}$ \\
\hline 2 & $\begin{array}{l}\text { Porosity of Schoepite, } \\
\text { fraction }\end{array}$ & $\begin{array}{l}\text { DTN: LL010902212241.026 [DIRS 163089], Rows } \\
1,2,3\end{array}$ & $0.05,0.15,0.30$ \\
\hline 3 & $\begin{array}{l}\text { Molecular weight of } \\
\text { Schoepite }\end{array}$ & $\begin{array}{l}\text { Lide and Frederikse } 1997 \text { [DIRS 103178], pp. 4-14 } \\
\text { to } 4-31\end{array}$ & 322.1 (calculated) $\mathrm{g} / \mathrm{mol}$ \\
\hline 4 & $\begin{array}{l}\text { Density and molecular } \\
\text { weight of } \mathrm{UO}_{2}\end{array}$ & Lide and Frederikse 1997 [DIRS 103178], pp. 4-94 & $10.97 \mathrm{~g} / \mathrm{cm}^{3}, 270 \mathrm{~g} / \mathrm{mol}$ \\
\hline 5 & Fuel rods/assembly & Preble et al. [DIRS 107407] Table A.1 & 264 \\
\hline 6 & Active fuel rod length, $\mathrm{cm}$ & Preble et al. [DIRS 107407] Table A.1 & 144 in. $(366 \mathrm{~cm})$ \\
\hline 7 & Fuel pellet diameter & Preble et al. [DIRS 107407] Table A.1 & $0.3225 \mathrm{in} .(0.819 \mathrm{~cm})$ \\
\hline 8 & $\begin{array}{l}\text { Distribution of failed } \\
\text { cladding, as-received }\end{array}$ & $\begin{array}{l}\text { S. Cohen \& Associates } 1999 \text { [DIRS 135910], p. 6- } \\
\text { 11, Table 6.2, Row } 1\end{array}$ & $\begin{array}{l}0.1 \% \text { expected value, } \\
\text { range } 0.01 \% \text { to } 1 \%\end{array}$ \\
\hline
\end{tabular}




\subsection{CRITERIA}

The following acceptance criteria, or portions therefrom, from Yucca Mountain Review Plan, Final Report (NRC 2003 [DIRS 163274]) were identified as applicable to this analysis report. A detailed description is available in the referenced document. These criteria were identified in the technical work plan (BSC 2005 [DIRS 172622]). The detail on how these criteria have been addressed is provided in Section 7.3.

1. System Description and Demonstration of Multiple Barriers, Acceptance Criteria (NRC 2003 [DIRS 163274], Section 2.2.1.1.3). The barriers are to be adequately identified and described (including time periods, uncertainty). The technical basis for the barrier capability is adequately presented, commensurate with the importance of the barrier.

2. Degradation of Engineered Barriers, Acceptance Criteria (NRC 2003 [DIRS 163274], Section 2.2.1.3.1.3). System description and analysis integration for the degradation of the barriers are adequate. Analysis adequately addresses design features, physical phenomena, and couplings and uses appropriate assumptions. Boundary and initial conditions used are propagated appropriately and consistently. Data are sufficient for analysis. Data uncertainty is characterized and propagated through the abstraction.

3. Mechanical Disruption of Engineered Barriers, Acceptance Criteria (NRC 2003 [DIRS 163274], Section 2.2.1.3.2.3). System description and integration for the mechanical disruption of the barriers are adequate. Data on mechanical disruptions are sufficient for analysis. Data uncertainty for mechanical disruptions are characterized and propagated through the abstraction.

4. Radionuclide Release Rates and Solubility Limits, Acceptance Criteria (NRC 2003 [DIRS 163274], Section 2.2.1.3.4.3). System description and analysis integration are adequate. Data are sufficient for analysis. Data uncertainty is characterized and propagated through the abstraction. Uncertainty is characterized and propagated through the abstraction. The abstraction output is supported by objective comparisons.

\subsection{CODES AND STANDARDS}

American Society for Testing and Materials (ASTM) Standard C 1174-97 [DIRS 105725], Standard Practice for Prediction of the Long-Term Behavior of Materials, Including Waste Forms, Used in Engineered Barrier Systems (EBS) for Geological Disposal of High-Level Radioactive Waste, is used to support the degradation analysis development methodology, categorize the analysis developed with respect to its usage for long-term TSPA-LA, and relate the information/data used to develop the analysis to the requirements of the standard. 


\section{INTENTIONALLY LEFT BLANK}




\section{ASSUMPTIONS}

\subsection{STAINLESS-STEEL-CLAD FUEL}

Assumption: It is assumed in this analysis report that there is a finite probability that the contents of any transportation cask arriving at the Yucca Mountain site that contains only stainless-steelclad assemblies will be loaded into three waste packages. This would result in about $3.5 \%$ of the total waste packages that would contain stainless-steel-clad assemblies. This assumption is necessary because it addresses an absence of direct confirming evidence of how the waste packages are to be loaded.

Rationale: Because there are no reactors currently operating that use stainless steel cladding, the total number of fuel assemblies with this cladding is fixed. EPRI (1996 [DIRS 160968]) gives a value of 2,118 such assemblies, while S. Cohen \& Associates (1999 [DIRS 135910]) gives a value of 2,179 . The larger value is used herein. These assemblies could be loaded into about 86 waste packages (Section 6.2.2). Since the total number of CSNF waste packages is 7,472 (BSC 2004 [DIRS 170022]), the percentage of waste packages that could contain stainless-steel-clad fuel rods is about $1.15 \%$. It is conceivable that a delivery of stainless steel assemblies at the repository in a cask containing, for example, 21 or more PWR assemblies, could be distributed into three waste packages. This is possible either due to the fact that all of the stainless steel could not be accommodated in one waste package or that the stainless steel assemblies, which are cooler, could be used to fill up waste packages containing hotter, fresher fuel assemblies. Thus, three times $1.15 \%$ would yield a potential number of $3.45 \%$ (which is rounded up to $3.5 \%$ ), indicating that about $3.5 \%$ of the total waste packages might contain SNF with stainless steel cladding.

Confirmation Status: The product of waste packages containing stainless-steel-clad fuel rods and fraction of stainless steel in each waste package is constant (i.e., there is a fixed amount of stainless-steel-clad fuel rods). Thus, the assumption of a value of $3.5 \%$ of waste packages that contain stainless steel assemblies is reasonable and slight variations in this distribution are not expected to have significant impact on dose to the public. Thus, it does not require confirmation.

Use in the Analysis: This assumption is used in Sections 6.2.2 and 7.4.2.

\subsection{ROCK OVERBURDEN}

Assumption: It is assumed in this analysis report that the cladding can begin to fail from mechanical (static) loading when a minimum of $20 \%$ (with a uniform distribution of $20 \%$ to $50 \%$ ) of the patches (rectangular areas established to facilitate corrosion calculations) on both the waste package and drip shield surface are corroded open. At the $50 \%$ level of corroded patches, failure of the waste package and hence the cladding by static overburden is likely. The lower value of $20 \%$ is uncertain, but reasonable and conservative as a lower bound. Section 6.6 of Seismic Consequence Abstraction (BSC 2004 [DIRS 169183]) states that no rockfall is expected on waste packages as a result of protection provided by the drip shields for the first 10,000 years. Thus, the $20 \%$ value is reasonable and conservative. It is further assumed that the fraction of failed fuel rods increases linearly with the number of waste package patch openings and the fuel is $100 \%$ failed when an additional $50 \%$ of the waste package patches are open. This assumption is necessary because there is an absence of direct confirming data or evidence that would allow a firm determination of when such a event might be postulated to occur. 
Rationale: Section 6.2 of Breakage of Commercial Spent Nuclear Fuel Cladding by Mechanical Loading (CRWMS M\&O 1999 [DIRS 136105]) concluded that static loading from rock overburden onto the fuel assemblies would fail the cladding. The rocks are postulated to fall onto the waste package after the drip shield fails and well before the waste package fails. The surface of the waste package is divided into patches in the TSPA-SR model (CRWMS M\&O 2000 [DIRS 153246]) as well as the TSPA-LA model (see BSC 2004 [DIRS 169996]). It is postulated that corrosion causes these patches to open. The location of corroded patches is randomly distributed on the waste package surface. As the patches open on the waste package, the rocks slowly load the cladding. The cladding failure starts when sufficient waste package patches are open to permit rock pressure to start static loading the assemblies. There is uncertainty in the prediction of when the corroded waste package starts to buckle; thus, it is assumed that cladding starts to fail when between $20 \%$ and $50 \%$ of the waste package patches are open and is completed when an additional $50 \%$ of the waste package patches are open.

Confirmation Status: Since this assumption is reasonable and conservative, it does not require confirmation.

Use on the Analysis: This assumption is used in Section 6.2.3.

\subsection{INSTANT SPLITTING}

Assumption: It is assumed in this analysis report that the cladding instantly splits along its length when the cladding is perforated if the waste package has failed. This assumption is necessary because it addresses an absence of direct confirming evidence of how cladding might split when the waste package fails. Note that initially intact cladding can fail due to rock overburden as noted in Section 5.2.

Rationale: The basis for this assumption is past experience with dry splitting of Zircaloy-clad LWR fuel rods due to spent fuel oxidation, wet splitting of BWR rods, and wet splitting of PWR rods in the Argonne National Laboratory (ANL) tests. The former tests are described in Section 6.3.4. For these tests, splitting was observed to occur rapidly after an incubation time was achieved. Note, however, that the incubation time is a function of temperature and perhaps relative humidity.

ANL has performed fuel degradation tests with two intentionally failed fuel segments in humid air at $175^{\circ} \mathrm{C}$ (Cunnane et al. 2003 [DIRS 162406]). These conditions are more severe than the repository conditions. The cladding on both of these test samples split axially in less than two years. Thus, it is conservatively assumed that BWR and PWR fuel rods will split instantly after waste package breach if they contain perforations at the time of emplacement.

It is also assumed that the rods clad with stainless steel will also split once the waste package has failed. This is based on the conservative assumption that all of the stainless-steel-clad fuel rods will contain perforations. Stainless steel is more susceptible to general corrosion and stress corrosion cracking than Zircaloy and the Alloy 22 waste package material. Thus, it is unlikely that credit for the stainless steel cladding would be defendable.

Confirmation Status: Since this assumption is conservative and consistent with experimental observations, it does not require confirmation.

Use on the Analysis: This assumption is used in Sections 6.1.2, 6.2.2, and 6.2.4. 


\section{SCIENTIFIC ANALYSIS DISCUSSION}

This section contains the development of a cladding degradation analysis. It starts with a discussion of cladding as a barrier. The various parts of the cladding degradation abstraction analysis are then discussed. Alternative scientific approaches are presented and a summary of included features, events, and processes (FEPs) is presented. A discussion of uncertainties completes this section. The following list contains the source for information used to develop and corroborate the analysis:

1.* FY01 Supplemental Science and Performance Analyses, Volume 2: Performance Analyses (BSC 2001 [DIRS 154659]), TSPA with alternative cladding degradation model

2. Risk Information to Support Prioritization of Performance Assessment Models (BSC 2003 [DIRS 168796]), analysis with naval fuels

3. Seismic Consequences Abstraction (BSC 2004 [DIRS 169183]), seismic event occurrences, rockfall impact

4. Total System Performance Assessment - 1995: An Evaluation of the Potential Yucca Mountain Repository (CRWMS M\&O 1995 [DIRS 100198]), TSPA excluding cladding

5. Total System Performance Assessment-Viability Assessment (TSPA-VA) Analyses Technical Basis Document (CRWMS M\&O 1998 [DIRS 100362]), inclusion of cladding in TSPA

6. Breakage of Commercial Spent Nuclear Fuel Cladding by Mechanical Loading (CRWMS M\&O 1999 [DIRS 136105]), mechanical failure of cladding

7.* Total System Performance Assessment for the Site Recommendation (CRWMS M\&O 2000 [DIRS 153246]), sensitivity studies

8.* Clad Degradation - Dry Unzipping (CRWMS M\&O 2000 [DIRS 149230]), dry oxidation splitting model

9.* Clad Degradation - Summary and Abstraction (CRWMS M\&O 2001 [DIRS 151662]), fuel as-received failures

10. Yucca Mountain Project Report, Waste Form Testing Work (Cunnane et al. 2003 [DIRS 162406]), cladding axial splitting

11. Evaluation of the Candidate High-Level Radioactive Waste Repository at Yucca Mountain Using Total System Performance Assessment, Phase 5 (EPRI 2000 [DIRS 154149]), inclusion of cladding in TSPA

12. Effectiveness of Fuel Rod Cladding as an Engineered Barrier in the Yucca Mountain Repository (S. Cohen \& Associates 1999 [DIRS 135910]), fuel reliability 
13. "Sensitivity Studies of the Effect of Cladding Degradation on TSPA Results" (Siegmann and Devonec 2002 [DIRS 160787]), sensitivity studies

14.* Performance Assessment of U.S. Department of Energy Spent Fuels in Support of Site Recommendation (BSC 2001 [DIRS 152059]), comparison of naval to CSNF.

15. Pitting Model for Zirconium-Alloyed Cladding (BSC 2004 [DIRS 170043]), pitting of Zircaloy.

16. Dry Cask Storage Characterization Project (EPRI 2002 [DIRS 161421]), dry storage tests, testing of fuel from dry storage canisters

17. “Transportation in France" (Debes 1999 [DIRS 161193]), fuel failures during transport

18. Assorted references listed in Table 6-2, fuel reliability

19. Transportation Accident Scenarios for Commercial Spent Fuel (Wilmot 1981 [DIRS 104724]), structural strength of spent nuclear fuel

20. Shipping Container Response to Severe Highway and Railway Accident Conditions (Fischer et al. 1987 [DIRS 104774]), structural strength of spent nuclear fuel

21. "Dynamic Impact Effects on Spent Fuel Assemblies" (Witte et al. 1989 [DIRS 102158]), structural strength of spent nuclear fuel, failure rates of fuel rods

22. A Method for Determining the Spent-Fuel Contribution to Transport Cask Containment Requirements (Sanders et al. 1992 [DIRS 102072]), structural strength of spent nuclear fuel

23. "A Review of Fuel Degradation in BWRs" (Edsinger 2000 [DIRS 154433]), splitting of cladding

24. "Axial Splits in Failed BWR Fuel Rods" (Lysell et al. 2000 [DIRS 154432]), splitting of cladding

25. Results from NNWSI Series 1 Spent Fuel Leach Tests (Wilson 1985 [DIRS 102147]), Results from Cycles 1 and 2 of NNWSI Series 2 Spent Fuel Dissolution Tests (Wilson 1987 [DIRS 102150]), Results from NNWSI Series 3 Spent Fuel Dissolution Tests (Wilson 1990 [DIRS 100793]), release of radionuclides through split cladding.

Note that the documents marked with asterisks have been cancelled, but are still relevant to this report. The cancelled documents were originally prepared during the site characterization process and are archived but are not kept up to date. They contain useful historical information. They are all qualified for their intended use within this report since they meet the requirements of LP-SIII.9Q-BSC, Section, 5.2.1(1) specifically because there are prior uses of the data and there are corroborating data available. The information contained in these reports was not impacted by the cancellation process. 
This analysis report describes the cladding degradation process that is to be incorporated into the TSPA-LA model as an abstraction. Cladding degradation consists of two stages, cladding failure (perforation) followed by axial splitting of the cladding. "Axial splitting" was referred to as "unzipping" in earlier DOE publications, but the terminology has been changed to "axial splitting" because this term is widely used in the nuclear industry. Cladding failure is the formation of cracks or holes in the cladding from various sources. The sources of cladding failure that are abstracted into the TSPA-LA model are failures during reactor operation and subsequent storage (including other operations before being received at the repository) and mechanical failure (breaking of the cladding). Unfailed (not perforated) cladding is expected to remain intact for the 10,000-year regulatory period since no credible mechanism has been identified that could cause perforation of the cladding in the inert and benign conditions existing inside an unfailed waste package. Cladding failure permits the fuel inside the cladding to begin to react with water or moist air and potentially leads to the splitting of the cladding. In the splitting stage, the cladding is axially split open by the formation of secondary mineral phases (higher oxides of $\mathrm{UO}_{2}$, commonly called rind on the fuel, or by fuel-side oxidation of the Zircaloy), making the radionuclides available for release. The split widens as the rind forms and radionuclides diffuse through the split opening. The various components of the abstraction are discussed below.

Fuel damage resulting from handling at the repository surface facility is considered to be negligible. Fuel damage from postreactor handling operations, other than consolidation, was estimated to be $0.0003 \%$ (S. Cohen \& Associates 1999 [DIRS 135910], p. 7-1) to 0.0005\% (CRWMS M\&O 2001 [DIRS 151662], Section 6.4.1). These low failure rates show that handling errors do not make a significant contribution to fuel failure rates.

Naval Nuclear Propulsion Program cladding/SNF performance is discussed in Naval Nuclear Propulsion Program Technical Support Document for the License Application, which is a classified document. Based upon the results from a sensitivity study performed for the TSPASR, (BSC 2001 [DIRS 152059]), waste packages containing naval fuel are conservatively analyzed as containing CSNF. There are 300 waste packages containing naval SNF compared to the commercial SNF inventory of approximately 7,500 waste packages. A comparison with an equivalent amount of Zircaloy-clad CSNF indicates that the total dose from the TSPA simulation, using the commercial-fuel equivalent, is more than four orders of magnitude higher than the total dose from the source-term simulation for naval SNF (BSC 2001 [DIRS 152059], p. 36 and Figure 6.1-2). Therefore, it is conservative to analyze naval SNF as CSNF.

In addition, an international peer review of the TSPA-SR model was performed that included cladding performance (OECD and IAEA 2002 [DIRS 158098], p. 33). The peer review found that the approach taken by the DOE for cladding was appropriate. They also state that:

The issue of cladding performance is important because it is one area of possible optimism and because it has a major effect on system performance beyond 10,000 years.

\subsection{CLADDING AS A BARRIER}

Per 10 CFR 63.2 [DIRS 156605], the waste form is one of the recognized barriers that significantly decrease the mobility of radionuclides. That integrity, in large part, depends on the 
material that encases the actual fuel, the cladding. Cladding prevents the environment from interacting with the fuel pellets by limiting the water or moist air from contacting and interacting with the fuel pellets and reduces radionuclide transport by reducing the diffusion area.

\subsubsection{Barrier Capability}

All CSNF currently in use in the United States (both PWR and BWR fuel) consists of assemblies of Zircaloy tubing filled with $\mathrm{UO}_{2}$ fuel pellets. Zircaloy is used because it is resistant to corrosion and has favorable neutronic properties. It has good mechanical properties that enable it to be made into long thin-walled tubing. The first function of the cladding, as a barrier, is to prevent water or moist air from contacting the fuel pellets. The cladding is completely sealed and only fuel with failed cladding can interact with water or moist air. Some cladding could be damaged before it is received at the repository. The distribution of failed cladding as-received is discussed in Section 4.1. The expected value is $0.1 \%$. After repository closure, the cladding could fail due to mechanical causes. Mechanical failure could occur from events associated with seismic activities such as rockfall or rock overburden. The seismic events can occur at any time and are addressed in a specific seismic TSPA calculation as described in Seismic Consequences Abstraction (BSC 2004 [DIRS 169183]). Cladding failure from rock overburden occurs as the waste package and drip shield become severely degraded and no longer protect the fuel from the static loading of the collapsed drift, which does not occur in the 10,000-year regulatory period (BSC 2004 [DIRS 169183], Section 6.6). Note that drip shield failure by separation due to vibratory ground motion has been excluded (BSC 2004 [DIRS 169183], Section 6.5.5).

After the cladding fails, water or moist air can enter the fuel rod and interact with the fuel pellets. This interaction releases the soluble fission products and actinides that are bound up in the pellet and also increases the volume of the pellet by forming less dense phases. Corrosion of the interior of the cladding is also possible. The increases in volume of the pellet or cladding can axially split the cladding, permitting greater fuel surface area to be exposed to the environment. Failed cladding still somewhat retards radionuclide mobilization by limiting the amount of water or moist air that can contact the pellet and reduces radionuclide transport by reducing the diffusion area for radionuclide release. In the analysis for TSPA-LA, no credit is taken for failed cladding limiting the amount of water or moist air contacting the fuel but credit is taken for cladding reducing the release of radionuclides because of the limited diffusion area through the split cladding (Section 6.2.4).

\subsubsection{Barrier Time Period of Function}

Cladding deterioration is analyzed in two steps, failure (perforation) and splitting. Failures may occur as a result of seismic events or from mechanical failure due to the static load of rock overburden. Seismic events and resultant failures may occur at any time. However, no significant cladding failures are predicted to occur after emplacement until both the waste package and drip shield have failed.

Splitting of previously perforated cladding starts when the waste package fails, permitting water or moist air into the package. After waste package failure, any previously failed cladding is assumed to split immediately. Uncertainty exists regarding the time period required for splitting to occur. ANL (Cunnane et al. 2003 [DIRS 162406]), has performed fuel degradation tests with 
two intentionally failed fuel segments in humid air at $175^{\circ} \mathrm{C}$. Both of these fuel segments split in less than two years, a very rapid time scale in terms of the TSPA-LA model. Although the temperature of the waste package internals are not expected to be this high after waste package breach (except for the case of postulated early waste package failure when little moisture is present), splitting may also occur at lower temperatures, perhaps at a lower rate. Therefore, the TSPA-LA model utilizes the assumption that the cladding is instantly split (Assumption 5.3) when both waste package and cladding perforation exists, leaving the fuel pellets exposed for corrosion.

\subsubsection{Barrier Uncertainty}

The uncertainties associated with the analysis for failing the cladding are described in this report and included in the TSPA-LA model. The uncertainty in the fraction of fuel that is failed asreceived at the repository is based on observed fuel reliability from reactor operation and conservative predictions for other activities after removal from the reactor. The uncertainties in the splitting of the cladding are large. Thus, a conservative approach was taken for the splitting of the cladding. Since a conservative analysis (instantaneous splitting) is used, no uncertainty is used in this portion of the TSPA-LA model.

\subsubsection{Barrier Consistency with TSPA}

Barrier performance in terms of preventing water or moist air from contacting the fuel is characterized in the TSPA-LA model. As-received failures and failures from seismic and rock overburden are included in the TSPA-LA model. No credit is included in the TSPA-LA for reduced or slowed reaction by the fuel pellets with the environment after cladding failure. In the TSPA-LA model, the fuel pellets corrode at the forward rate of reaction as if they were bare pellets after cladding failure. This is conservative since any oxygen starvation or moisture limitations would reduce the corrosion rate. The failed cladding does reduce the rate at which the radionuclides would be released. Diffusion of radionuclides across the split opening is calculated. The full family of sensitivity studies, performed for TSPA-SR, showed that TSPA results are not sensitive to the splitting (see, for example, Siegmann and Devonec 2002 [DIRS 160787]).

\subsection{COMMERCIAL FUEL ROD CLADDING DEGRADATION ABSTRACTION ANALYSIS}

ASTM C1174-97 [DIRS 105725] establishes guidance for the development of models/analyses used for the degradation of engineered barrier system materials based on physical laws, conceptual models, and relatively short-term, compared to repository time frame, experimental observations. The highest-level approach is purely mechanistic and is based on first principles. When purely mechanistic approaches are unavailable or unobtainable, semi-empirical approaches can be utilized. Lastly, purely empirical approaches can be utilized that describe the observed material responses and dependencies on variables without reference to specific mechanisms. Since detailed mechanistic approaches or the data to support them are not available, this latter empirical approach is utilized herein to develop the cladding degradation analysis. Note also that this approach is utilized to model the chemical conditions that could cause pitting of zirconium cladding (Section 6.2.5). 
The cladding degradation analysis consists of four elements, which are described in the following sections including cladding condition as-received, stainless steel cladding distribution, mechanical failure of cladding, and split cladding. These elements are based on assumptions provided in Section 5. Discussion is also provided on pitting corrosion for completeness. It is not an input to TSPA-LA.

\subsubsection{Cladding Condition As-Received}

The important element of the cladding condition as-received at the repository is the fraction of failed cladding, which is taken from the analysis by S. Cohen \& Associates (1999 [DIRS 135910], p. 6-11, Table 6.2, Row 1). Incipient failures were not included in that analysis. This reference gives an expected value of as-received failed cladding as $0.1 \%$ with a range of $0.01 \%$ to $1 \%$. The expected value is interpreted to be the median value. A log uniform distribution is applied to the range 0.01 to 1 because it gives equal weight to the full distribution and addresses the large (two orders of magnitude) size of the uncertainty. The median value of $0.095 \%$ and a maximum value of $1.29 \%$ calculated in Clad Degradation - Summary and Abstraction (CRWMS M\&O 2001 [DIRS 151662], p. 65) corroborates the median and maximum values obtained by S. Cohen \& Associates (1999 [DIRS 135910]). The uncertainties in terms of the range are carried forward into the abstraction.

S. Cohen \& Associates (1999 [DIRS 135910]) reviewed the cladding conditions and failure modes for as-received fuels. Table 6-1 gives their components of failure percents and causes. S. Cohen \& Associates (1999 [DIRS 135910], p. 2-31) also concluded that damage of fuel during shipment, if any, would be minor. The as-received failure rates in this analysis is compared to rates from other alternative scientific approaches in Section 6.3.1 and to other reported values shown below.

Table 6-1. Fuel Failure Rates

\begin{tabular}{|l|c|}
\hline \multicolumn{1}{|c|}{ Fuel Service Period } & Rod Failure $\%$ \\
\hline In-Service & $<0.05$ \\
\hline Pool Storage & 0 \\
\hline Dry Storage & 0.03 \\
\hline Consolidation & 0.005 \\
\hline Other Handling & 0.0003 \\
\hline Total & $<0.1$ \\
\hline
\end{tabular}

Source: S. Cohen \& Associates 1999 [DIRS 135910], p. 7-1.

The as-received failed fuel rods are available to undergo clad splitting and fuel-pellet corrosion when the waste package fails. This parameter is summarized for TSPA-LA input as Item 1 of Table 7-1.

An earlier report (CRWMS M\&O 2001 [DIRS 151662], p. 65) reviewed the various causes of fuel damage and independently produced very similar results (median $0.095 \%$, range $0.0155 \%$ to $1.29 \%$ ) for the rod failure rate for all causes. These results are close to the results achieved with this analysis and corroborates the values selected. 
The initial cladding failure rate from reactor operation and associated activities is further evaluated using experimental data developed independently and available in the published literature and industry reports. Table 6-2 gives the failure rate reported by others for various times and conditions. These support the values used in this analysis. ANL has tested rods that have been in dry storage for approximately 15 years and have reported no signs of cladding degradation (EPRI 2002 [DIRS 161421]). Fuel failures from transportation are unlikely and not included in Table 2. Debes (1999 [DIRS 161193], p. 2) reported that no anomalies, such as fuel leakage, have been detected after transporting 27,000 assemblies in France. Thus, these outside sources confirm the values selected in this analysis.

Table 6-2. Comparison of Fuel Reliability from Various Sources

\begin{tabular}{|c|c|c|c|}
\hline Fuel & Period & Reference & Failure Rate $^{\mathrm{a}}, \%$ \\
\hline GE-8 $\times 8$ & 1983 & Bailey et al. 1985, p. 1-3 [DIRS 109191] & 0.007 \\
\hline PWR-French & $\begin{array}{l}1979 \text { to } 1984 \\
1984\end{array}$ & Dehon et al. 1985 [DIRS 109197], p. 2-24 & $\begin{array}{l}0.001-0.01 \\
0.005\end{array}$ \\
\hline $\begin{array}{l}\text { BWR-Japan } \\
\text { PWR-Japan }\end{array}$ & To 1997 & $\begin{array}{l}\text { Sasaki and Kuwabara } 1997 \text { [DIRS 102074], } \\
\text { pp. } 13,14\end{array}$ & $\begin{array}{l}0.01 \\
0.002\end{array}$ \\
\hline PWR-CE & To $11 / 1984$ & $\begin{array}{l}\text { Andrews and Matzie } 1985 \text { [DIRS 109190], } \\
\text { p. 2-42, Table } 2\end{array}$ & 0.011 \\
\hline All & Through 1984 & EPRI 1997 [DIRS 100444], p. 4-1 & $0.02-0.07$ \\
\hline All & After 1984 & EPRI 1997 [DIRS 100444], p. 4-2 & $0.006-0.03$ \\
\hline $\begin{array}{l}\text { BWR } \\
\text { PWR }\end{array}$ & To 1986 & Sanders et al. 1992 [DIRS 102072], p. I-36 & $\begin{array}{l}0.10-0.73 \\
0.07-0.48\end{array}$ \\
\hline PWR-Westinghouse & $\begin{array}{l}1 \text { core, debris damage } \\
\text { after steam generator } \\
\text { replacement }\end{array}$ & $\begin{array}{l}\text { McDonald and Kaiser } 1985 \text { [DIRS 101725], } \\
\text { pp. 2-4 and 2-5 }\end{array}$ & 0.26 \\
\hline All & 1969 to 1976 & $\begin{array}{l}\text { Manaktala } 1993 \text { [DIRS 101719], pp. 3-2 and } \\
\text { 3-3, Figure 3-1 }\end{array}$ & $0.01-2+$ \\
\hline PWR-Mark B-B\&W & 1986 to 1996 & $\begin{array}{l}\text { Ravier et al. } 1997 \text { [DIRS 102068], p. 34, } \\
\text { Figure } 4\end{array}$ & $0-0.055$ \\
\hline BWR & 2000 & Edsinger 2000 [DIRS 154433], p. 162 & 0.0005 \\
\hline BWR, GE Fuel & 1995 to 1999 & Potts 2000 [DIRS 160783], p. 502, Figure 1 & 0.00058 \\
\hline $\begin{array}{l}\text { PWR, Mitsubishi } \\
\text { Fuel }\end{array}$ & 1992 to 1999 & Doi et al. 2000 [DIRS 160781], p. 443 & 0 rod failures \\
\hline
\end{tabular}

NOTES: B\&W = Babcock \& Wilcox; CE = Combustion Engineering GE = General Electric; $W=$ Westinghouse.

${ }^{a}$ Failure rates are on a rod basis unless noted as assembly-based. The assembly value represents the percentage of assemblies that contain at least one failed rod.

\subsubsection{Stainless Steel Cladding Distribution}

The stainless steel cladding degradation distribution element uses both the fraction of stainless-steel-clad fuel assemblies in the repository and the distribution of these assemblies among the spent fuel-containing waste packages.

The total number of fuel rods with stainless steel cladding is fixed since there are no operating reactors using this cladding. As indicated by S. Cohen \& Associates (1999 [DIRS 135910]), there are 2,179 such assemblies in storage, either at the reactor sites or at General Electric's Morris, Illinois facility. This total consists of 1,846 PWR assemblies (84.7\% of the total) and 
333 BWR assemblies (15.3\% of the total). If these are loaded into 21-PWR and 44-BWR waste packages containing only stainless steel cladding, this represents 88 PWR waste packages (1,846 PWR assemblies/21 PWR assemblies per waste package) and 8 BWR waste packages (333 BWR assemblies/44 BWR assemblies per waste package). However, it is likely that the approximately $10 \%$ of the fuel that is grossly failed (EPRI 1996 [DIRS 160968]) would not be included in the mandated 60,000 MTU of SNF (grossly failed fuel would likely be relegated to the end of the line of shipments since they represent only a small fraction of the total and the requirements for such shipments have not yet been developed). Thus, the total of 96 waste packages would be reduced to about 86 waste packages that would be included in the repository loading of 7,472 CSNF waste packages given in Table 4-2 of Initial Radionuclide Inventories (BSC 2004 [DIRS 170022]). This then represents about $1.15 \%$ of the total number of waste packages containing commercial SNF. As noted in Assumption 5.1, each receipt of stainlesssteel-clad fuel could be loaded into three waste packages, bringing the percentage of waste packages that could contain stainless steel up to about $3.5 \%$.

The 7,472 waste packages contain 220,810 CSNF assemblies (BSC 2004 [DIRS 170022], Table 4-2). Since there are 2,179 assemblies with stainless steel cladding, the percentage of assemblies in the repository with stainless steel cladding would be $2,179 \times 100 / 220,810$ or $0.99 \%$ (rounded to $1.0 \%$ ). Since it is assumed that $3.5 \%$ of the waste packages contain stainless-steelclad assemblies (Assumption 5.1), then on average a waste package with stainless-steel-clad assemblies would contain $1.0 \% \times 100 / 3.5 \%$ or $28.6 \%$ stainless steel and $71.4 \%$ Zircaloy-clad assemblies.

Fuel rods with stainless steel cladding were used in the early generation LWR core designs but are no longer used. In the TSPA-SR and the TSPA-LA analyses, the stainless-steel-clad fuel rods are assumed to be perforated upon placement, making them immediately available for splitting when the waste package fails (See Assumption 5.3). Due to the conservative nature of the assumption, no uncertainty has been assigned to the failure probability for stainless-steel-clad fuel.

For the TSPA-LA analysis, an uncertainty for the distribution of stainless-steel-clad fuel into waste packages is developed here using Assumption 5.1. If the deliveries to the repository were always timed so that all deliveries always required partial loading into a new waste package, then the number of waste packages containing stainless-steel-clad fuel assemblies could double to about $7 \%$ and the stainless-steel-clad fuel rod content of these waste packages would halve to about $15 \%$. This uncertainty is an epistemic uncertainty since it is due to the lack of knowledge of the loading of the stainless-steel-clad assemblies. Because of the general uncertainty in waste package loading patterns, the fraction of waste packages containing stainless-steel-clad fuel rods will be taken as uniformly distributed between $3.5 \%$ and $7 \%$ of the waste packages.

The percentage of stainless-steel-clad rods is calculated as follows:

$$
\mathrm{X}=\frac{100 \% \times 1.0 \%}{\mathrm{Y}}
$$

where

$\mathrm{X}=$ percentage of stainless-steel-clad rods in the waste package

$\mathrm{Y}=$ percentage of waste packages containing stainless-steel-clad fuel rods. 
The parameters for TSPA-LA are summarized as Items 2 and 3 of Table 7-1. It is also noted that, since the postclosure performance of the repository as developed in the TSPA-SR was not sensitive to the distribution of the stainless-steel-clad assemblies within waste packages, it is not likely to be sensitive to this parameter in the TSPA-LA. As noted in Section 6.3.2, distributing the stainless-steel clad fuel among all waste packages is not conservative since it spreads out the release and lowers the peak dose.

\subsubsection{Mechanical Failure of Cladding}

The two forms of mechanical failure of the cladding considered in the TSPA-LA model are seismic-induced failure (including rockfall) and mechanical failure from the static load of a rock overburden. Rockfall will not directly impact the cladding since the waste package and drip shield will protect the waste form until they fail by corrosion processes (See Assumption 5.2).

The definition of the mathematical relationship for cladding failed due to rock overburden is in two steps:

i. Cladding failure will begin when both the fraction of drip shield patch openings and the fraction of waste package patch openings exceed the sampled uncertainty (0.2 to 0.5 , uniform distribution)

ii. After failure begins, the cladding failure fraction will depend linearly on only the fraction of waste package patches open (not the sum of waste package and drip shield patch fractions).

In the unlikely event that both the waste package and drip shield fail, a rubble bed of rocks from the collapse of the drift is assumed to mechanically load the exposed fuel rods. This load will fail the cladding (CRWMS M\&O 1999 [DIRS 136105], Section 6.2). For estimating the peak dose, rubble bed damage to the cladding can not be neglected.

The proposed element uncertainty has been assumed (Assumption 5.2). Failure of the cladding starts when a minimum of $20 \%$, with a uniform distribution of $20 \%$ to $50 \%$, of the patches on both the drip shield and waste package surface are corroded open. The fraction of rods failed is then assumed to increase linearly with increased waste package surface opening (patches) until all the rods are failed when an additional $50 \%$ of the waste package patches are open (Assumption 5.2). The way that the TSPA-LA model predicts when patches (defined rectangular areas) on the waste package surface are corroded through is provided in WAPDEG Analysis of Waste Package and Drip Shield Degradation (BSC 2004 [DIRS 169996], Section 6.3.2). This is an epistemic uncertainty since it is due to a lack of knowledge of how the waste package and drip shield will fail and when the weight of the rocks will be loaded onto the fuel. The cladding will fail using the following relationship (Assumption 5.2):

$$
\% \text { Rods failed }=200 \times(P F-X)
$$

where:

$\mathrm{PF}=$ waste package patch fraction, in range $\mathrm{X} \leq \mathrm{PF} \leq \mathrm{X}+0.5$

$\mathrm{X}=$ random number, uniformly distributed in range $0.2 \leq \mathrm{X} \leq 0.5$ 
The percentage of rods failed is limited to less than or equal to $100 \%$. This parameter is summarized for TSPA-LA input as Item 4 of Table 7-1. Confidence in the parameters selected has been enhanced by comparing the parameter assumptions with results of alternative scientific analysis approaches and experimental data developed independently and available in the published literature and industry reports.

Failure of the cladding from the force of the rock overburden qualitatively resembles the structural analysis in Section 5.3 of Breakage of Commercial Spent Nuclear Fuel Cladding by Mechanical Loading (CRWMS M\&O 1999 [DIRS 136105]). This analysis concluded that the fuel could not support the weight of the rock overburden. This overburden mechanically presses on the fuel after the drip shield and waste package deteriorate to the extent that the fuel no longer supports the weight of the rock overburden.

The robustness of the cladding to extreme forces has been addressed in many transportation studies, which show that significant forces are required to fail the fuel demonstrating that the parameter is conservative. These studies are dynamic rather than static, but they add confidence in the robustness of the fuel rods. Wilmot (1981 [DIRS 104724], Table VII) recommends the use of $71 \mathrm{~g}$ accelerations (where $\mathrm{g}$ is the gravitational constant) for the failure threshold for fuel rods experiencing side impacts. He references an experimental threshold of $122 \mathrm{~g}$ for SNF. Wilmot noted that, in drop tests, rods were bent with end impacts of $38 \mathrm{~g}$ but did not fail. He references experimental thresholds for end impacts of 234 g. Fischer et al. (1987 [DIRS 104774], Figure 8-3) suggested that $10 \%$ of the rods might fail with a $40 \mathrm{~g}$ end impact, and $100 \%$ might fail with a $100 \mathrm{~g}$ end impact. Witte et al. (1989 [DIRS 102158], Table 3) report that the acceleration needed to fail rods from side impact varies from $63 \mathrm{~g}$ to $211 \mathrm{~g}$, depending on the fuel design. Sanders et al. (1992 [DIRS 102072], Attachment III) present detailed structural analysis of various assemblies under impacts and give (Table III-10) the probability of rod failure from 9 meter drops of transportation casks. All these references show the robustness of spent fuel rods to failure from mechanical loading. The literature data cited above shows that the rods have significant strength and adds confidence that the element that assumes that the rods break from a significant amount of rock overburden is conservative.

\subsubsection{Split Cladding}

After the waste package and cladding fail, water or moist air can enter the fuel rod and interact with the fuel pellets. This can cause an increase in the volume of the pellet due to the formation of higher oxides of uranium (such as schoepite). This atmosphere can also lead to oxidation of the exposed inner surface of the cladding. The increase in volume of the pellet or cladding interior surface will cause axial splitting of the cladding. Over time, this splitting will extend over the full active length of the rod (listed as 366-cm in Item 6 of Table 4-1), exposing a greater fuel surface area to the environment. Cladding with preexisting flaws splits when the waste package fails (Assumption 5.3). Intact cladding starts to split when the cladding fails but only after waste package failure. ANL has performed fuel degradation tests with two intentionally perforated fuel segments in humid air at $175^{\circ} \mathrm{C}$ (Cunnane et al. 2003 [DIRS 162406]). These conditions are more severe than the anticipated repository conditions, since the cladding will approach ambient temperatures after a few thousand years. After waste package failure, the waste package interior atmosphere will become air saturated with humidity but not pure steam. Both of the ANL fuel segments split in less than two years, a rapid time scale in terms of the 
TSPA model. As a result, for the TSPA-LA input, the cladding is assumed to instantly split, since it occurs rapidly in comparison to an expected TSPA time step (Assumption 5.3), leaving the fuel pellets exposed for corrosion. No uncertainty is assigned to the analysis since it is conservative and results in splitting being effectively instantaneous over expected TSPA-LA repository time steps.

Edsinger (2000 [DIRS 154433], p. 173) reports a lower bound velocity of splitting for a BWR rod of the range of 1 to $3 \mathrm{~mm} / \mathrm{hr}$ for these experiments. Lysell et al. (2000 [DIRS 154432], p. 217) report axial splitting velocities of about $3 \mathrm{~mm} / \mathrm{hr}$ after an incubation time. Their data were collected either in-reactor at about $240^{\circ} \mathrm{C}$ or in the laboratory at about $200^{\circ} \mathrm{C}$ to $300^{\circ} \mathrm{C}$. These velocities do not address incubation times but would lead to bare fuel pellets in a very short time compared to TSPA time steps (100 to 1,000 year time steps).After the cladding has split, it still surrounds the fuel pellets, holds them into the original fuel geometry, and limits the amount of water or moist air that contacts the fuel and limits the release of radionuclides. However, in this analysis, the entire surface area is conservatively assumed to be available for corrosion processes to occur. While rapid axial splitting of fuel rod cladding has been observed in the ANL tests and in operating BWR reactors, such splitting has not observed in spent fuel pools for time periods of 30 years. Neither has axial splitting been observed in operating PWR reactors where there is less coolant boiling, a more reducing environment due to a hydrogen overpressure, and thus a lower concentration of dissolved oxygen in the water. Only the $\mathrm{UO}_{2}$ in failed fuel rods is available to corrode. After splitting, the fuel pellets along the complete length of the rod are available to corrode. Corrosion starts when the waste package fails and water or moist air enters. The width of the split increases with time as the $\mathrm{UO}_{2}$ corrodes to form a secondary alteration product, commonly called the rind.

Table 6-3 and Table 6-4 describe the mathematical relationships for how the split opens as the fuel pellet corrodes. For fuel under repository conditions, the rind is schoepite. Schoepite $\left(\mathrm{UO}_{3} 2 \mathrm{H}_{2} \mathrm{O}\right)$ is formed when the fuel $\left(\mathrm{UO}_{2}\right)$ reacts with oxygen and water (or water vapor) at temperatures below $90^{\circ} \mathrm{C}$. At higher temperatures, dehydrated schoepite forms. Given the short time that higher temperatures exist after waste package breach, using schoepite properties is a good approximation and is conservative since schoepite has a lower density than dehydrated schoepite. The mass of the rind is increased from the $\mathrm{UO}_{2}$ mass by the ratio of the molecular weights of the two minerals since water and oxygen are combined to form schoepite. The density of the (schoepite) rind, including porosity, ranges from 3.4 to $4.6 \mathrm{~g} / \mathrm{cm}^{3}$ with a mean value of $4.0 \mathrm{~g} / \mathrm{cm}^{3}$ (combination of Items 1 and 2 from Table 4-1). The uncertainty in the porosity input is carried forward through the analysis to be uncertainty in diffusion parameters. The small amount of porosity of the unreacted $\mathrm{UO}_{2}$ fuel pellets is neglected in the density value given in Table 6-3 and Table 6-4.

The volume ratio (volume rind/volume $\mathrm{UO}_{2}$ ) is calculated using Equation 6-3, shown in Table 6-4, and ranges from 2.8 to 3.8 with a mean value of 3.3. Note that the small amount of porosity in the unreacted $\mathrm{UO}_{2}$ is conservatively ignored. The total volume of fuel in the waste package is calculated with Equation 6-4 using Items 5 through 7 in Table 4-1 and recognizing that there are 5,544 rods (21 assemblies $\times 264$ rods per assembly) in the 21-PWR assembly waste package. Both the corrosion rate and the amount of fuel that is corroded are calculated by the TSPA code using the temperature and chemistry conditions. The number of failed rods is the product of the total number of rods times the rod failure fraction (Equation 6-5). The volume of 
unreacted fuel in a rod is given in Equation 6-6. The volume of the rind in a fuel rod is the product of the volume of corroded $\mathrm{UO}_{2}$ times the volume rind multiplier (Equation 6-7). For conservatism, the small amount of uranium that dissolves is ignored and all the uranium is taken to be precipitated as rind. The cladding is filled with $\mathrm{UO}_{2}$ and rind giving a new diameter based on the equation for the volume of a cylinder (Volume $\left.=(\pi / 4) \mathrm{D}^{2} \mathrm{~L}\right)$. Equation 6-8 gives the new rod diameter.

Table 6-3. Input Variables to Calculate Cladding Split Geometry

\begin{tabular}{|l|l|l|l|}
\hline \multicolumn{1}{|c|}{ Name } & \multicolumn{1}{c|}{ Units } & \multicolumn{1}{c|}{ Description } & \multicolumn{1}{c|}{ Definition } \\
\hline $\mathrm{MW}_{-} \mathrm{UO}_{2}$ & $\mathrm{~g} / \mathrm{mol}$ & Molecular weight of $\mathrm{UO}_{2}$ & $270 \mathrm{~g} / \mathrm{mol}$ \\
\hline $\mathrm{MW} \_\mathrm{sch}$ & $\mathrm{g} / \mathrm{mol}$ & Molecular weight of schoepite & $322.1 \mathrm{~g} / \mathrm{mol}$ \\
\hline $\mathrm{DUO}_{2}$ & $\mathrm{~g} / \mathrm{cm}^{3}$ & Density of $\mathrm{UO}_{2}$ & $10.97 \mathrm{~g} / \mathrm{cm}^{3}$ \\
\hline $\mathrm{Dsch}$ & $\mathrm{g} / \mathrm{cm}^{3}$ & Theoretical density of schoepite & $4.83 \mathrm{~g} / \mathrm{cm}^{3}$ \\
\hline Por & None & Porosity in schoepite & 0.05 to 0.30, uniformly distributed \\
\hline $\mathrm{Lr}$ & $\mathrm{cm}$ & Rod length & $366 \mathrm{~cm}$ \\
\hline $\mathrm{Nr}$ & None & $\begin{array}{l}\text { Number of Rods per waste } \\
\text { package }\end{array}$ & $5544(264 \times 21$ assemblies/WP) \\
\hline Dinit & $\mathrm{cm}$ & Initial pellet diameter & $0.819 \mathrm{~cm}$ \\
\hline Frod(t) & None & Fraction of rods that are failed & $\begin{array}{l}\text { Initially 0.0001-0.01, mean of 0.001, } \\
\text { then calculated by TSPA-LA model }\end{array}$ \\
\hline Fcor(t) & None & $\begin{array}{l}\text { Fraction of total waste package } \\
\text { inventory that has corroded }\end{array}$ & $\begin{array}{l}\text { WAPDEG calculation } \\
\text { (not calculated in this analysis report) }\end{array}$ \\
\hline
\end{tabular}

Source: Table 4-1 
Table 6-4. Calculated Variables and Equations to Calculate Cladding Split Geometry

\begin{tabular}{|l|l|l|l|c|}
\hline \multicolumn{1}{|c|}{ Name } & \multicolumn{1}{c|}{ Units } & \multicolumn{1}{c|}{ Description } & \multicolumn{1}{c|}{ Definition } & Equation \\
\hline $\mathrm{VRM}$ & None & Volume rind ratio multiplier & $\begin{array}{l}\left(\mathrm{MW}-\mathrm{sch} / \mathrm{MW}-\mathrm{UO}_{2}\right)^{*} \mathrm{DUO}_{2} /((1-\mathrm{Por}) \\
\times \mathrm{Dsch})\end{array}$ & $6-3$ \\
\hline $\mathrm{VI}$ & $\mathrm{cm}^{3}$ & Initial volume of fuel in a waste package & $\mathrm{Nr} \times \mathrm{Lr} \times \pi \times \operatorname{Dinit}^{2} / 4$ & $6-4$ \\
\hline $\mathrm{Nf}(\mathrm{t})$ & $\mathrm{None}$ & Number of failed rods & $\mathrm{Frod}(\mathrm{t}) \times \mathrm{Nr}$ & $6-5$ \\
\hline $\mathrm{Vfr}(\mathrm{t})$ & $\mathrm{cm}^{3}$ & $\begin{array}{l}\text { Volume of } \mathrm{UO}_{2} \text { in } 1 \text { failed rod available for } \\
\text { corrosion }\end{array}$ & $\mathrm{VI} \times(\mathrm{Frod}(\mathrm{t})-\mathrm{Fcor}(\mathrm{t})) / \mathrm{Nf}(\mathrm{t})$ & $6-6$ \\
\hline $\mathrm{Vrr}(\mathrm{t})$ & $\mathrm{cm}^{3}$ & Volume Rind in a rod & $\mathrm{VI} \times \mathrm{Fcor}(\mathrm{t}) \times \mathrm{VRM} / \mathrm{Nf}(\mathrm{t})$ & $6-7$ \\
\hline $\operatorname{Drf}(\mathrm{t})$, & $\mathrm{Cm}$ & Diameter of rod $\left(\mathrm{UO}_{2}+\right.$ rind $)$ & $V(4 \times(\mathrm{Vfr}(\mathrm{t})+\operatorname{Vrr}(\mathrm{t})) /(\mathrm{Lr} \times \pi))$ & $6-8$ \\
\hline $\operatorname{Dif} \operatorname{Dist}(\mathrm{t})$ & $\mathrm{Cm}$ & $\begin{array}{l}\text { Average Diffusion distance; } \\
(\text { volcanic case })\end{array}$ & $\operatorname{Drf}(\mathrm{t}) / 2 ;(\operatorname{Dif} \operatorname{Dist}(\mathrm{t})=\operatorname{Drf}(\mathrm{t}) / 4)$ & $6-9$ \\
\hline $\mathrm{SO}(\mathrm{t})$ & $\mathrm{Cm}$ & Split Opening; $($ volcanic case $)$ & $\pi \times(\operatorname{Drf}(\mathrm{t})-\operatorname{Dinit}) ;(\mathrm{SO}(\mathrm{t})=\pi \times \operatorname{Drf}(\mathrm{t}))$ & $6-10$ \\
\hline $\mathrm{A} \mathrm{Dif}(\mathrm{t})$ & $\mathrm{cm}^{2}$ & Area for diffusion from split & $\mathrm{Nf}(\mathrm{t}) \times \mathrm{SO}(\mathrm{t}) \times \mathrm{Lr}$ & $6-11$ \\
\hline $\mathrm{Vw}(\mathrm{t})$ & $\mathrm{cm}^{3}$ & Volume of water in the rind & $\mathrm{Por} \times \operatorname{Vrr}(\mathrm{t}) \times \mathrm{Nf}(\mathrm{t})$ & $6-12$ \\
\hline
\end{tabular}

The average diffusion distance for radionuclides from the rod to adjacent metallic corrosion products in the waste package is half of the rod diameter (Equation 6-9). For the volcanic scenario, the cladding is conservatively assumed to be oxidized and provides no barrier to the release of radionuclides. Thus, for this case, the average diffusion distance is one fourth of the rind and the unreacted $\mathrm{UO}_{2}$ diameter (Equation 6-9). The split opening is the difference between the current rod circumference and the initial rod circumference (Equation 6-10). The split can occur at any orientation around the rod circumference. Since, the conversion of $\mathrm{UO}_{2}$ to schoepite does not lead to additional cracking or powdering, relocation is not considered in the analysis. The total area for diffusion of radionuclides from the rind in the failed rods to adjacent metallic corrosion products in the waste package is the product of rod length, split opening, and number of failed rods in a waste package (Equation 6-11). Water vapor may also collect in the pores of the rind. The volume of water available for dissolution of radionuclides in the rind is equal to the porosity of the rind times the rind volume (Equation 6-12).

The split will continue to widen until all of the $\mathrm{UO}_{2}$ in the fuel rod has corroded and then a steady-state geometry exists. The time to completely corrode the fuel rod depends on the waste package temperature and in-package chemistry but generally requires less than 2,000 years following exposure based upon the forward reaction rate for $\mathrm{UO}_{2}$. The diffusion through the cladding split continues until all of the soluble radionuclides are released. The clad splitting parameters for the TSPA-LA model are summarized at Items 5 through 10 in Table 7-1.

The rind analysis describes the release of radionuclides through the split opening. C. Wilson performed a series of tests measuring the release of radionuclides through a segment of fuel rod with a slit cut in it (Wilson 1985 [DIRS 102147]; Wilson 1987 [DIRS 102150]; Wilson 1990 [DIRS 100793]). The slit was cut into the cladding to simulate a split. He also performed the test with similar samples of fuel with the cladding removed. This permits a comparison of the reduction of the release in radionuclides caused by the split cladding. Wilson observed large reductions in the release of radionuclides. As an example, in his series three tests, cycles 1 and 2 
(Wilson 1990 [DIRS 100793], Table 3.1), he observed the release of uranium was reduced by a factor of about 170 .

\subsubsection{Localized Corrosion Degradation}

Pitting of zirconium alloy cladding was discussed in Pitting Model for Zirconium-Alloyed Cladding (BSC 2004 [DIRS 170043]). In that report, the potential for crevice corrosion and stress corrosion cracking was also briefly examined. Crevice corrosion was ruled out based on the lack of observations in the literature and in DOE experiments. Stress corrosion cracking (SCC) was also found to be unlikely since SCC would likely occur under the same environmental conditions as pitting and pitting was ruled out as discussed below. Justification of the decision to exclude from the TSPA-LA FEPs 2.1.02.15.0A, 2.1.02.16.0A, and 2.1.02.21.0A, related to localized corrosion of the cladding (see Table 6-1) is documented in Clad Degradation - FEPs Screening Arguments (BSC 2004 [DIRS 170019]).

Zirconium alloys are susceptible to pitting in a particularly aggressive combination of chloride $\left(\mathrm{Cl}^{-}\right)$ions, ferric ions $\left(\mathrm{Fe}^{+3}\right)$ or hydrogen peroxide $\left(\mathrm{H}_{2} \mathrm{O}_{2}\right)$. In order to predict cladding failure from chloride pitting, a review of the literature for pitting rates and electrochemical data for various zirconium alloys was conducted (see BSC 2004 [DIRS 170043]). Based on this review of the literature, failure criteria were constructed based on an electrochemical definition of pitting as the condition at which the corrosion potential exceeds repassivation potential (i.e., $\mathrm{E}_{\text {corr }}>\mathrm{E}_{\mathrm{rp}}$ ). Electrochemical values were obtained for zirconium alloys in various solution concentrations of $\mathrm{Cl}^{-}, \mathrm{Fe}^{+3}$, and $\mathrm{H}_{2} \mathrm{O}_{2}$ using data obtained from various experimental sources. The model to predict repassivation potential depends only on chloride concentration in the solution. The corrosion potential $\left(\mathrm{E}_{\text {corr }}\right)$ was modeled by doing a regression analysis to fit experimental data with varying molar concentrations of $\mathrm{Cl}^{-}, \mathrm{Fe}^{+3}$, and hydrogen peroxide $\left(\mathrm{H}_{2} \mathrm{O}_{2}\right)$. The range of concentrations used in the regression analysis is higher than the conditions expected in the repository. The model predicts the conditions where experimental pitting was observed. In-package chemistry analysis (that included radiolysis) was performed. When in-package chemistry results were combined with the cladding pitting model, no cladding failures were predicted and these FEPs (2.1.02.15.0A and 2.1.02.16.0A, see BSC 2004 [DIRS 170019], Table 6-1) were excluded from the TSPA-LA model.

\subsection{ALTERNATIVE SCIENTIFIC APPROACHES}

The TSPA performed for the repository in 1995 (CRWMS M\&O 1995 [DIRS 100198]) did not consider the effects of cladding. They consider the fuel as bare pellets. Bare pellets can be considered an alternative scientific approach that is extremely conservative because failure to consider cladding permits all fuel to dissolve at the intrinsic dissolution rate. A solubility limit, representing the solubility of the secondary phase, is used to limit the release rate of the fuel. In all TSPA calculations that include cladding degradation, one of the sensitivity studies is always the effect of removing the cladding. These sensitivity studies could also be considered alternative scientific approaches. Sensitivity studies (BSC 2003 [DIRS 168796], p. 3-13 and Table 2) compared TSPA with and without cladding and showed that cladding performance only had a small effect on the TSPA results and therefore was given an importance to expected risk as "Not Significant." 
Analyses performed in support of possible repository sites in Europe also did not consider cladding as a barrier to radionuclide release. Most European reactors are run at higher temperatures and go to higher burnup than U.S. reactors. The potential European sites are saturated, reducing, and hydrogen over-pressured environments where the $\mathrm{UO}_{2}$ corrosion rates are slow. As a result, in-repository cladding degradation would be slow, but the potential for damage prior to placement would be greater. Thus, cladding credit was not considered.

The cladding degradation analysis has evolved, and the earlier repository studies could also be considered alternative scientific approaches. Total System Performance Assessment-Viability Assessment (TSPA-VA) Analyses Technical Basis Document (CRWMS M\&O 1998 [DIRS 100362]) was the first study to include cladding as a barrier to radionuclide release. Cladding was included in FY01 Supplemental Science and Performance Analyses, Volume 2: Performance Analyses (BSC 2001 [DIRS 154659]) and Total System Performance Assessment for the Site Recommendation (CRWMS M\&O 2000 [DIRS 153246]). The Electric Power Research Institute (EPRI) included cladding degradation in their analysis (EPRI 2000 [DIRS 154149], p. 5-35) based on general corrosion. Their model concludes that cladding reduces doses in the periods 30,000 to 200,000 years (EPRI 2000 [DIRS 154149], p. 13-5).

Siegmann and Devonec (2002 [DIRS 160787]) performed a series of sensitivity studies that showed the effect of using many of these alternative scientific approaches in Total System Performance Assessment for the Site Recommendation (TSPA-SR) (CRWMS M\&O 2000 [DIRS 153246]). This study concluded that the exclusion of cladding degradation would increase the peak dose rate by only about a factor of three from the TSPA-SR model.

Thus, this alternative scientific approach was rejected since it is overly conservative. As noted above, this condition will be evaluated via a sensitivity analysis.

\subsubsection{Cladding Condition As-Received}

In the TSPA-SR model, the values used for the fraction of cladding that has failed prior to emplacement are an alternative conceptual model (CRWMS M\&O 2001 [DIRS 151662], p. 65). This analysis developed values $(0.095 \%$ median value, range $0.0155 \%$ to $1.29 \%)$ that are close to the values developed by S. Cohen \& Associates (1999 [DIRS 135910], Table 6.2) to be used in the TSPA-LA model $(0.1 \%$ median value, range $0.01 \%$ to $1 \%)$. Since they are similar, the use of this alternative scientific approach would not affect the TSPA-LA results. Another alternative approach would be to assume that all cladding is failed upon receipt. Siegmann and Devonec (2002 [DIRS 160787], Figure 2) show that even under this extremely unlikely scenario, the effect would only be approximately triple the peak dose compared to the base case model with no effect during the first 10,000 years.

Thus, this alternative scientific approach was rejected since it was similar to the results of the analysis developed in this report.

\subsubsection{Stainless Steel Cladding Distribution}

The quantity of commercial spent fuel with stainless steel cladding is fixed since no current fuel manufacturer is using stainless steel. An alternative scientific approach could have the stainlesssteel-clad fuel distributed equally into all the waste packages rather than the base case of loading 
into a limited number of waste packages. This distribution could reduce the peak dose by spreading out the release from the stainless-steel-clad fuel rods. However, this is an unlikely alternative since the current surface design calls for loading waste packages as the fuel arrives on the site and blending the stainless-steel-clad fuel would be limited. As noted in the previous paragraph, the TSPA-LA is not expected to be that sensitive to the fraction of failed fuel. Thus, this alternative scientific approach is rejected as being unlikely and nonconservative.

\subsubsection{Mechanical Failure of Cladding}

There are no alternative scientific approaches to the development of the elements that have been identified for the mechanical failure of the cladding.

\subsubsection{Split Cladding}

An alternative scientific approach to instant splitting that is described in this report is the splitting due to dry oxidation. The dry oxidation model (CRWMS M\&O 2000 [DIRS 149230]) considers the further oxidation of $\mathrm{UO}_{2}$ to $\mathrm{U}_{3} \mathrm{O}_{8}$. This occurs in a relatively dry environment (humidity below 50\%). After an initial incubation time, the rods are observed to split very quickly as a result of the increase in volume of the $\mathrm{U}_{3} \mathrm{O}_{8}$ from $\mathrm{UO}_{2}$. Because of humidity and temperature limits, it is unlikely that dry splitting will occur in a postclosure waste package. The instant splitting analysis presented in this report is conservative with respect to splitting times if dry oxidation should occur. Thus, the alternative scientific approach of dry splitting is rejected since it is unlikely and leads to results similar to the wet splitting analysis.

The rind model used for the TSPA-SR model could be considered an alternative scientific approach for the release of radionuclides from the split rod. The rind volume was just the original volume of the $\mathrm{UO}_{2}$, increased by porosity. The presence of the split cladding was neglected and the only diffusion considered was through the crack or patch in the waste package. Since this approach leads to very conservative releases, this alternative scientific approach was rejected.

\subsubsection{Summary of Alternative Scientific Approach Considerations}

The alternative scientific approaches considered for cladding degradation are summarized in Table 6-5. The summary shows (Column 3 of Table 6-5) that most of the alternative scientific approaches are less appropriate for use in the TSPA-LA model because they are overly conservative or reflect conditions not expected in the repository. 
Table 6-5. Alternative Scientific Approaches Considered

\begin{tabular}{|l|l|l|}
\hline \multicolumn{1}{|c|}{$\begin{array}{c}\text { Alternative Scientific } \\
\text { Approaches }\end{array}$} & \multicolumn{1}{|c|}{ Key Assumptions } & \multicolumn{1}{c|}{ Screening Assessment and Bases } \\
\hline No Cladding Credit & $\begin{array}{l}\text { Bare fuel when waste package } \\
\text { fails. }\end{array}$ & $\begin{array}{l}\text { Overly conservative. Addressed in TSPA-LA } \\
\text { as a sensitivity study. }\end{array}$ \\
\hline $\begin{array}{l}\text { TSPA-SR Initial Cladding } \\
\text { Failures }\end{array}$ & $\begin{array}{l}\text { Addresses various causes of fuel } \\
\text { failure. }\end{array}$ & Similar results to this analysis. \\
\hline $\begin{array}{l}\text { Stainless-Steel-Clad Fuel } \\
\text { Evenly Distributed }\end{array}$ & $\begin{array}{l}\text { Stainless-steel-clad fuel evenly } \\
\text { distributed in all waste packages. }\end{array}$ & $\begin{array}{l}\text { Even distribution considered highly } \\
\text { improbable. Not conservative. }\end{array}$ \\
\hline Splitting - Dry Oxidation & $\mathrm{UO}_{2}$ forms $\mathrm{U}_{3} \mathrm{O}_{8}$. & $\begin{array}{l}\text { Unlikely because it requires low humidity, } \\
\text { high temperatures, produces instant splitting } \\
\text { as current analysisl. }\end{array}$ \\
\hline TSPA-SR Rind Model & $\begin{array}{l}\text { No cladding present, only diffusion } \\
\text { out of waste package. }\end{array}$ & $\begin{array}{l}\text { Overly conservative. Similar to No Cladding } \\
\text { Credit. }\end{array}$ \\
\hline
\end{tabular}

\subsection{FEATURES, EVENTS, AND PROCESSES ADDRESSED}

The development of a comprehensive list of FEPs potentially relevant to postclosure performance of a repository at Yucca Mountain is an ongoing, iterative process based on site-specific information, design, and regulations. Particular FEPS are either included or excluded depending on their relevance to each model/analysis report in accordance with their assignment in the LA FEP list (DTN: MO0407SEPFEPLA.000 [DIRS 170760]).

Table 6-6 provides a list of FEPs that are used in this analysis and in the TSPA-LA. Specific reference to the various sections within this document where issues related to each FEP are addressed is provided in the table. The detailed discussion of these FEPs, implementation in TSPA-LA and the exclusionary arguments are documented in Clad Degradation - FEPS Screening Arguments (BSC 2004 [DIRS 170019]).

Table 6-6. Included FEPs for this Analysis Report

\begin{tabular}{|c|l|l|}
\hline FEP Number & \multicolumn{1}{|c|}{ LA-FEP Name } & \multicolumn{1}{|c|}{ Section Where Disposition is Described } \\
\hline LA:2.1.02.12.0A & $\begin{array}{l}\text { Degradation of cladding prior } \\
\text { to disposal }\end{array}$ & Sections 6.2.1, 6.2.2 \\
\hline LA:2.1.02.23.0A & $\begin{array}{l}\text { Cladding Unzipping (Axial } \\
\text { Splitting) }\end{array}$ & Sections 6.2.4, 6.3.4 \\
\hline LA:2.1.09.03.0A & $\begin{array}{l}\text { Volume increase of corrosion } \\
\text { products impacts cladding }\end{array}$ & Sections 6.2.4, 6.3.4 \\
\hline LA:2.1.02.25.0B & Naval SNF cladding & Section 6.0 \\
\hline
\end{tabular}

\subsection{UNCERTAINTIES}

Uncertainties from inputs, and the four elements were carried forward to the abstraction. The input values for the fraction of cladding failed as-received contained two orders of magnitude uncertainty. The fraction of CSNF that is clad in stainless steel is fixed and no uncertainty was considered. The input loading pattern for the stainless-steel-clad fuel into waste packages did not have any uncertainty but one was developed in this analysis report. No uncertainty is used for the fraction of stainless-steel-clad fuel that is failed; an upper limit is used. There are no 
direct input uncertainties to the mechanical failure element that need to be propagated to the abstraction. An uncertainty in when the cladding starts to fail is introduced in this analysis report and carried forward to the abstraction. A conservative analysis of instant splitting of the cladding was used without any uncertainty. The uncertainty in rind porosity was included in the input and is carried forward to the abstraction. There is also an uncertainty in $\mathrm{UO}_{2}$ corrosion rates and chemical and temperature environments inside the waste package. These uncertainties are generated in the TSPA-LA calculations and are carried forward into the abstraction and produce an uncertainty in the rind geometry and diffusion of radionuclides from the fuel rind. The uncertainties in the cladding degradation analysis are epistemic type. 


\section{CONCLUSIONS}

\subsection{OUTPUT TO THE TSPA-LA MODEL}

Table 7-1 provides the parameters developed in this cladding degradation analysis that serve as inputs to TSPA-LA. The information in Table 7-1, along with the related uncertainties, are included in DTN: MO0411SPACLDDG.003. Note that there are some small differences in this DTN and its predecessor MO0306SPACLDDG.002. Firstly, the percentage of CSNF with stainless steel cladding was originally given as $1.04 \%$, rather than $1.0 \%$. Secondly, the theoretical density of schoepite was corrected from 4.87 to $4.83 \mathrm{~g} / \mathrm{cm}^{3}$. Lastly, the pellet diameter was corrected from 0.82 to $0.819 \mathrm{~cm}$. These changes were made to account for changes in the source documents. These changes do not significantly impact TSPA-LA results.

This DTN is restricted to repository designs where the cladding surface temperature is less than $350^{\circ} \mathrm{C}$ during postclosure. Some of the clad degradation input parameters used in earlier analyses have been eliminated and details of their exclusion from the TSPA-LA model are documented in Clad Degradation - FEPs Screening Arguments (BSC 2004 [DIRS 170019]). The cladding degradation values used in the four elements of the cladding degradation analysis are summarized below.

Table 7-1. Summary of Cladding Degradation Values to be Used in the TSPA-LA Model

\begin{tabular}{|l|l|l|l|}
\hline Item & \multicolumn{1}{|c|}{ Input name } & TSPA Parameter Name & \multicolumn{1}{|c|}{ Values } \\
\hline 1 & $\begin{array}{l}\text { Distribution of failed cladding, as- } \\
\text { received }\end{array}$ & Initial_Rod_Failures & $\begin{array}{l}\text { Range 0.01 to 1\%, log uniform } \\
\text { distribution, Epistemic Uncertainty }\end{array}$ \\
\hline 2 & $\begin{array}{l}\text { Stainless-steel-clad fuel loading into } \\
\text { waste packages }\end{array}$ & Frac_CSNF_Pkgs_SS & $\begin{array}{l}\text { Waste packages containing } \\
\text { stainless-steel-clad fuel = 3.5 to 7\%, } \\
\text { uniformly distributed, Epistemic } \\
\text { Uncertainty }\end{array}$ \\
\hline 3 & $\begin{array}{l}\text { Percentage of total commercial SNF } \\
\text { inventory with stainless steel cladding }\end{array}$ & Inven_SS & $1.0 \%$ \\
\hline 4 & Rock overburden uncertainty factor & Rock_Load_Uncertainty & $\begin{array}{l}\text { Uniformly distributed between 0.2 } \\
\text { and } 0.5, \text { Epistemic Uncertainty }\end{array}$ \\
\hline 5 & $\begin{array}{l}\text { Fraction of fuel available for corrosion at } \\
\text { any TSPA time step }\end{array}$ & Fuel_Split_Fraction & 1.0 \\
\hline 6 & Density of UO 2 & Density_UO2 & $10.97 \mathrm{~g} / \mathrm{cm}^{3}$ \\
\hline 7 & Density of Schoepite & Density_Schoepite & $4.83 \mathrm{~g} / \mathrm{cm}^{3}$ (calculated) \\
\hline 8 & Molecular weight of UO 2 & MW_UO2 & $270 \mathrm{~g} / \mathrm{mol}^{2}$ \\
\hline 9 & Molecular weight of schoepite & MW_schoepite & $322.1 \mathrm{~g} / \mathrm{mol}$ (calculated) \\
\hline 10 & Por, Porosity in rind & Rind_Porosity_CSNF & $\begin{array}{l}\text { Uniformly distributed between } 0.05 \\
\text { and } 0.3, \text { Epistemic Uncertainty }\end{array}$ \\
\hline 11 & Lr, Active fuel rod length, cm & Rod_Length_CSNF & $366 \mathrm{~cm}$ \\
\hline 12 & Nr, Number of rods per waste package & Num_Rods_WP_CSNF & 5,544 \\
\hline 13 & Dinit, Initial pellet diameter & Pellet_Diameter_CSNF & $0.819 \mathrm{~cm}^{2}$ \\
\hline
\end{tabular}

Output: DTN: MO0411SPACLDDG.003 


\subsubsection{Cladding Condition As-Received}

The groups of waste packages represented in the TSPA-LA model have an initial percentage of failed rods defined by the log uniform distribution with a range $0.01 \%$ to $1 \%$. This fuel rod failure rate is based on historical data on reactor operation and includes uncertainty. It also includes failure from wet and dry storage at the reactor site, and handling. This percentage of rods is available for radionuclide release through fast release and splitting when the waste package fails. As-received cladding failures are discussed in Section 6.2.1.

\subsubsection{Stainless Steel Cladding Distribution}

The abstraction places the fuel with stainless steel cladding into waste packages as it arrives at the repository. This analysis results in $3.5 \%$ to $7 \%$ (uniformly distributed) of the waste packages that contain stainless-steel-clad fuel rods. The total amount of stainless-steel-clad fuel is fixed at approximately $1.0 \%$ of the total commercial spent nuclear fuel (CSNF). These waste packages contain $30 \%$ to $15 \%$ stainless-steel-clad fuel rods, which are assumed to be failed and available for instantaneous splitting when the waste package fails. Stainless-steel-clad fuel is discussed in Section 6.2.2.

\subsubsection{Mechanical Failure of Cladding}

Static loading from fallen rocks fails the cladding. Failure starts when both the fraction of drip shield patches and the fraction of waste package patches open exceed the sampled value for the rock overburden uncertainty fraction. This uncertainty fraction is given by a uniform distribution, sampled between 0.2 and 0.5 . Failure increases linearly to $100 \%$ rod failure when an additional $50 \%$ of the waste package patches are open. This is a reasonable and conservative assumption based on the very low cladding failure rates observed in the reactor industry. Mechanical failure is discussed in Section 6.2.3.

\subsubsection{Split Cladding}

Fuel rods that have previously failed are assumed to split (cladding axially splits down their length) instantaneously once the waste package has failed. This is a conservative assumption that bounds the results of experimental observations. It leaves the fuel pellets exposed to the waste package internal environment. For TSPA-LA purposes, this statement implies that the fraction of the fuel in a failed rod that is available for corrosion, at any time, can be set to a constant value of one. For the rind calculations, the split in the cladding slowly widens as the $\mathrm{UO}_{2}$ corrodes because of the increase in volume of the corrosion products. The radionuclides diffuse through the split into the surrounding environment. Cladding splitting is discussed in Section 6.2.4.

\subsection{CONCLUSION}

In summary, the cladding degradation is analyzed in two stages in the TSPA-LA model: cladding failure and cladding splitting. The cladding degradation abstraction depends on the waste package surface patch corrosion rate. Uncertainties have been established for the important parameters, and the results vary for each TSPA-LA realization. Since the stainlesssteel clad fuel, which represents about $1 \%$ of the inventory, is assumed to be failed and the 
Zircaloy clad fuel contains up to $1 \%$ failed rods (see Section 4.1 ), then less than $2 \%$ of the total as-received cladding is taken as failed as a result of previous operations at the reactor site. The cladding is also assumed to begin to fail from rock overburden, after significant (20\% to $50 \%$ ) waste package and drip shield degradation. With the ranges and uncertainties included in the abstraction, this analysis is valid for its intended use, analyzing cladding degradation in the TSPA-LA model. The cladding degradation analysis is valid for cladding peak surface temperatures below $350^{\circ} \mathrm{C}$ during postclosure. This is within the presently anticipated operating limits for a repository at Yucca Mountain.

\subsection{YUCCA MOUNTAIN REVIEW PLAN ACCEPTANCE CRITERIA}

The CSNF waste form cladding meets the definition of a barrier as stated in 10 CFR 63.2 [DIRS 156605]. The acceptance criteria for the degradation of this barrier are given below along with the manner in which this analysis report complies with those criteria. These criteria are stated in the appropriate sections of Yucca Mountain Review Plan, Final Report (NRC 2003 [DIRS 163274]) shown below.

\subsubsection{Barriers (Section 2.2.1.1.3)}

\section{Acceptance Criterion 1 - Identification of Barriers is Adequate}

The pertinent portions of this criterion include the identification of the barrier and its link to barrier capability.

The description and link to the capability of cladding as a barrier is provided in Section 1 and Section 6.1.

\section{Acceptance Criterion 2 - Description of Barrier Capability to Isolate Waste is Acceptable}

The pertinent portions of the criterion include the capability of the barrier to reduce the release rate of radionuclides, the time over which it so functions, and the definition of the barrier.

The capability of the barrier to reduce the release rate of radionuclides, the time frame over which it functions, and its definition are found in Section 6.1

\section{Acceptance Criterion 3 - Technical Basis for Barrier Capability is Adequately Presented}

The pertinent portions of the criterion include the technical basis for performance assessment and the importance of the barrier.

The relationship of the barrier to performance assessment is described in Section 1 . The importance of the barrier is discussed in Sections 6.1.

\subsubsection{Barrier Degradation (Section 2.2.1.3.1.3)}

\section{Acceptance Criterion 1 - System Description and Model Integration are Adequate}


The pertinent portions of this criterion include the description of the engineered barrier, the models selected or developed, the assumptions made, and the support for screening arguments for features, events, and processes (FEPS). This model is not used directly by TSPA.

The description of cladding as a barrier is provided in Section 6.1. The elements selected or developed are provided in Section 6.2. Assumptions made and their bases are found in Section 5. The FEPs addressed in this report and support for related screening arguments are found in Section 6.4 .

\section{Acceptance Criterion 2 - Data are Sufficient for Model Justification}

The pertinent portions of this criterion include the parameters used to evaluate the degradation of the cladding, the available data utilized for the development of the models, and the development of the models themselves.

The parameters utilized are provided in along with the input data sources Section 4.1. The development of the analyses using these inputs is discussed in Section 6.2.

Acceptance Criterion 3 - Data Uncertainty is Characterized and Propagated Through the Model Abstraction

The pertinent portions of this criterion include the use of data sources within their appropriate ranges and a description of the uncertainty or variability, including probability distributions.

The data sources and their ranges of applicability are noted in Section 4.1, as well as their associated uncertainty.

\section{Acceptance Criterion 4 - Model Uncertainty is Characterized and Propagated Through the Model Abstraction}

The pertinent portions of this criterion include alternative modeling approaches and conceptual model uncertainties.

Alternative scientific approaches are noted in Section 6. The conceptual scientific approach uncertainties are found in Section 6.5. Alternative scientific approaches are found in Section 6.3.

\section{Acceptance Criterion 5 - Model Abstraction Output Is Supported by Objective Comparisons}

The appropriate portions of this criterion include comparisons of the model output with empirical observations or other mathematical models and the margin between actual and predicted degradation of the cladding is adequate.

The corroboration of the analyses developed and confidence building for the elements assumed, using Project information, alternative mathematical models, or information in the literature, is 
described in detail in Section 6.2. This section also shows the high degree of margin between anticipated and modeled failure rates and radionuclide releases.

\subsubsection{Mechanical Disruption of Engineered Barriers (Section 2.2.1.3.2.3)}

Acceptance Criteria 1-System Description and Model Integration are Adequate

The pertinent portions of this criterion include the description of the physical phenomena involved in the disruption process, assumptions and inputs used, and appropriate environmental conditions.

The physical phenomena are discussed in Sections 6.1 and 6.2.3. The assumptions are provided in Section 5 and inputs are provided in Section 4.1. The range of environmental conditions expected is discussed in Sections 6.1 and 6.2.3.

\section{Acceptance Criteria 2-Data are Sufficient for Model Justification}

The pertinent portion of the criterion include only the adequacy and use mechanical disruption data.

The source of the input data is provided in Section 4.1, while Section 6.2.3 describes how those data are used for the development of this analysis.

Acceptance Criteria 3-Data Uncertainty is Characterized and Propagated Through the Model Abstraction

The pertinent portions of the criterion include the model parameters, ranges, distributions, assumptions, and uncertainties.

The parameters, ranges, distributions and uncertainties are discussed in Section 6.2.3. Assumptions are described in Section 5.

Acceptance Criteria 4-Model Uncertainty is Characterized and Propagated Through the Model Abstraction

The pertinent portions of the criterion include the use of alternative modeling approaches and the consideration of features, events and processes.

The alternative scientific approaches are discussed in Section 6 and in Section 6.3. Features, events, and processes are discussed in Section 6.4.

\section{Acceptance Criteria 5-Model Abstraction Output is Supported by Objective Comparisons}

The pertinent portions of the criterion include the consistency of the results with empirical observations and the utilization of well documented procedures to conduct the tests. 
The consistency of the results with empirical observations is discussed in Section 6.2.2 and the procedures utilized to conduct the tests are noted, where applicable, in the discussion in Sections 4 and 6.2.3.

\subsubsection{Radionuclide Release Rates And Solubility Limits (Section 2.2.1.3.4.3)}

\section{Acceptance Criteria 1-System Description and Model Integration are Adequate}

The pertinent portions of this criterion include only the need to reasonably account for the range of environmental conditions expected inside breached waste packages.

Environmental conditions expected inside breached waste packages are discussed in Section 6.1.

Acceptance Criteria 2-Data are Sufficient for Model Justification

The pertinent portions of the criterion include the adequacy of the input data and how the data are used.

The data inputs are described in Section 4.1 and the use of the data is described in Section 6.2.

\section{Acceptance Criteria 3-Data Uncertainty is Characterized and Propagated Through the Model Abstraction}

The pertinent portions of the criterion include the model parameters, ranges, distributions, assumptions, and uncertainties.

The parameters, ranges, distributions and uncertainties are discussed in Section 6.2. Assumptions are described in Section 5.

\section{Acceptance Criteria 4-Model Uncertainty is Characterized and Propagated Through the Model Abstraction}

The pertinent portions of the criterion include the use of alternative modeling approaches and the consideration offeatures, events and processes.

The alternative scientific approaches are discussed in Section 6 and in Section 6.3. Features, events, and processes are discussed in Section 6.4.

\section{Acceptance Criteria 5-Model Abstraction Output is Supported by Objective Comparisons}

The pertinent portions of the criterion include the consistency of the results with empirical observations and the utilization of well documented procedures to conduct the tests.

The consistency of the results with empirical observations is discussed in Section 6.2 and the procedures utilized to conduct the tests are noted, where applicable, in the discussion in Sections 4 and 6.1. 


\section{INPUTS AND REFERENCES}

\subsection{DOCUMENTS CITED}

109190 Andrews, M.G. and Matzie, R.A. 1985. "A Report on the Reliability, Performance and Progress of Combustion Engineering's Fuel Assemblies Toward Extended Burnup." Proceedings, American Nuclear Society Topical Meeting on Light Water Reactor Fuel Performance, Orlando, Florida, April 21-24, 1985. DOE/NE/34130-1. Volume 1. La Grange Park, Illinois: American Nuclear Society. TIC: 226810.

109191 Bailey, W.E.; Marlowe, M.O.; and Proebstle, R.A. 1985. "Trends in BWR Fuel Performance." Proceedings, American Nuclear Society Topical Meeting on Light Water Reactor Fuel Performance, Orlando, Florida, April 21-24, 1985. DOE/NE/34130-1. Volume 1. La Grange Park, Illinois: American Nuclear Society. TIC: 226810.

154659 BSC (Bechtel SAIC Company) 2001. "Performance Analysis." Volume 2 of FY01 Supplemental Science and Performance Analyses. TDR-MGR-PA-000001 REV 00. Las Vegas, Nevada: Bechtel SAIC Company. ACC: MOL.20010724.0110.

152059 BSC 2001. Performance Assessment of U.S. Department of Energy Spent Fuels in Support of Site Recommendation. CAL-WIS-PA-000002 REV 00. Las Vegas, Nevada: Bechtel SAIC Company. ACC: MOL.20010627.0026.

168796 BSC 2003. Risk Information to Support Prioritization of Performance Assessment Models. TDR-WIS-PA-000009 REV 01 ICN 01, with errata. Las Vegas, Nevada: Bechtel SAIC Company. ACC: MOL.20021017.0045; DOC.20031014.0003.

168361 BSC 2004. Q-List. 000-30R-MGR0-00500-000-000 REV 00. Las Vegas, Nevada: Bechtel SAIC Company. ACC: ENG.20040721.0007. ACC: ENG.20040721.0007.

169183 BSC 2004. Seismic Consequence Abstraction. MDL-WIS-PA-000003, Rev. 01. Las Vegas, Nevada: Bechtel SAIC Company. ACC: DOC.20041025.0004.

172622 BSC 2005. Technical Work Plan for Postclosure Waste Form Modeling. TWP-WISMD-000014 REV 00. Las Vegas, Nevada: Bechtel SAIC Company. ACC: DOC.20050125.0007.

170019 BSC 2004. Clad Degradation - FEPs Screening Arguments. ANL-WIS-MD-000008, Rev. 02. Las Vegas, Nevada: Bechtel SAIC Company. ACC: DOC.20041020.0014.

169996 BSC 2004. WAPDEG Analysis of Waste Package and Drip Shield Degradation. ANL-EBS-PA-000001 REV 02. Las Vegas, Nevada: Bechtel SAIC Company. ACC: DOC.20041004.0005.

170043 BSC 2004. Pitting Model for Zirconium-Alloyed Cladding. MDL-WIS-MD-000001 REV 01. Las Vegas, Nevada: Bechtel SAIC Company. ACC: DOC.20040827.0009. 
170022 BSC 2004. Initial Radionuclide Inventories. ANL-WIS-MD-000020 REV 01. Las Vegas, Nevada: Bechtel SAIC Company. ACC: DOC.20040921.0003.

100198 CRWMS M\&O 1995. Total System Performance Assessment - 1995: An Evaluation of the Potential Yucca Mountain Repository. B00000000-01717-2200-00136 REV 01. Las Vegas, Nevada: CRWMS M\&O. ACC: MOL.19960724.0188.

100362 CRWMS M\&O 1998. "Waste Form Degradation, Radionuclide Mobilization, and Transport Through the Engineered Barrier System." Chapter 6 of Total System Performance Assessment-Viability Assessment (TSPA-VA) Analyses Technical Basis Document. B00000000-01717-4301-00006 REV 01. Las Vegas, Nevada: CRWMS M\&O. ACC: MOL.19981008.0006.

136105 CRWMS M\&O 1999. Breakage of Commercial Spent Nuclear Fuel Cladding by Mechanical Loading. CAL-EBS-MD-000001 REV 00. Las Vegas, Nevada: CRWMS M\&O. ACC: MOL.19991213.0237.

153246 CRWMS M\&O 2000. Total System Performance Assessment for the Site Recommendation. TDR-WIS-PA-000001 REV 00 ICN 01. Las Vegas, Nevada: CRWMS M\&O. ACC: MOL.20001220.0045.

149230 CRWMS M\&O 2000. Clad Degradation - Dry Unzipping. ANL-EBS-MD-000013 REV 00. Las Vegas, Nevada: CRWMS M\&O. ACC: MOL.20000503.0200.

151662 CRWMS M\&O 2001. Clad Degradation - Summary and Abstraction. ANL-WISMD-000007 REV 00 ICN 01. Las Vegas, Nevada: CRWMS M\&O. ACC: MOL.20010214.0229.

162406 Cunnane, J.; Ebert, W.; Goldberg, M; Finch, R.; and Mertz, C. 2003. "Yucca Mountain Project Report, Waste Form Testing Work. [Argonne, Illinois] Argonne National Laboratory, Chemical Technology Division. ACC: MOL.20030630.0418.

161193 Debes, M. 1999. “Transportation in France.” Letter from O. Dekens (EDF) to A.J. Machiels (EPRI), November 15, 1999, with attachment. TIC: 249077.

109197 Dehon, C.; Cambon, J.L.; Houdaille, B.; and Chagrot, M. 1985. "Main Results from FRAGEMA Fuel Performance in Power Reactors." Proceedings, American Nuclear Society Topical Meeting on Light Water Reactor Fuel Performance, Orlando, Florida, April 21-24, 1985. DOE/NE/34130-1. Volume 1. La Grange Park, Illinois: American Nuclear Society. TIC: 226810.

160781 Doi, S.; Suzuki, S.; Mori, M.; and Takahashi, T. 2000. "Advanced Fuel Design and Performance for Burnup Extension." Proceedings of the 2000 International Topical Meeting on Light Water Reactor Fuel Performance, Park City, Utah, April 10-13, 2000. La Grange Park, Illinois: American Nuclear Society. TIC: 248973.

154433 Edsinger, K. 2000. "A Review of Fuel Degradation in BWRs." Proceedings of the 2000 International Topical Meeting on Light Water Reactor Fuel Performance, Park 
City, Utah, April 10-13, 2000. La Grange Park, Illinois: American Nuclear Society. TIC: 248973.

160968 EPRI (Electric Power Research Institute) 1996. Evaluation of Expected Behavior of LWR Stainless Steel-Clad Fuel in Long-Term Dry Storage. EPRI TR-106440. Palo Alto, California: Electric Power Research Institute. TIC: 253649.

100444 EPRI 1997. The Technical Basis for the Classification of Failed Fuel in the Back-End of the Fuel Cycle. EPRI TR-108237. Palo Alto, California: Electric Power Research Institute. TIC: 236839.

154149 EPRI 2000. Evaluation of the Candidate High-Level Radioactive Waste Repository at Yucca Mountain Using Total System Performance Assessment, Phase 5. 1000802. Palo Alto, California: Electric Power Research Institute. TIC: 249555.

161421 EPRI 2002. Dry Cask Storage Characterization Project. EPRI TR-1002882. Palo Alto, California: Electric Power Research Institute. TIC: 253737.

104774 Fischer, L.E.; Chou, C.K.; Gerhard, M.A.; Kimura, C.Y.; Martin, R.W.; Mensing, R.W.; Mount, M.E.; and Witte, M.C. 1987. Shipping Container Response to Severe Highway and Railway Accident Conditions. NUREG/CR-4829. Volume 1.

Washington, D.C.: U.S. Nuclear Regulatory Commission.

ACC: NNA.19900827.0230.

103178 Lide, D.R. and Frederikse, H.P.R., eds. 1997. CRC Handbook of Chemistry and Physics. 78th Edition. Boca Raton, Florida: CRC Press. TIC: 243741.

154432 Lysell, G.; Grigoriev, V.; and Efsing, P. 2000. “Axial Splits in Failed BWR Fuel Rods." Proceedings of the 2000 International Topical Meeting on Light Water Reactor Fuel Performance, Park City, Utah, April 10-13, 2000. La Grange Park, Illinois: American Nuclear Society. TIC: 248973.

101719 Manaktala, H.K. 1993. Characteristics of Spent Nuclear Fuel and Cladding Relevant to High-Level Waste Source Term. CNWRA 93-006. San Antonio, Texas: Center for Nuclear Waste Regulatory Analyses. TIC: 208034.

101725 McDonald, S.G. and Kaiser, R.S. 1985. "The Impact of Metallic Debris on Fuel Performance - A Case History." Proceedings, American Nuclear Society Topical Meeting on Light Water Reactor Fuel Performance, Orlando, Florida, April 21-24, 1985. DOE/NE/34130-1. Volume 1. La Grange Park, Illinois: American Nuclear Society. TIC: 226810.

163274 NRC (U.S. Nuclear Regulatory Commission) 2003. Yucca Mountain Review Plan, Final Report. NUREG-1804, Rev. 2. Washington, D.C.: U.S. Nuclear Regulatory Commission, Office of Nuclear Material Safety and Safeguards. TIC: 254568.

158098 OECD (Organisation for Economic Co-operation and Development) and IAEA (International Atomic Energy Agency) 2002. An International Peer Review of the 
Yucca Mountain Project TSPA-SR, Total System Performance Assessment for the Site Recommendation (TSPA-SR). Paris, France: Organisation for Economic Co-operation and Development, Nuclear Energy Agency. TIC: 252385.

160783 Potts, G.A. 2000. “Recent GE BWR Fuel Experience.” Proceedings of the 2000 International Topical Meeting on Light Water Reactor Fuel Performance, Park City, Utah, April 10-13, 2000. La Grange Park, Illinois: American Nuclear Society. TIC: 248973.

107407 Preble, E.A.; Painter, C.L.; Avlis, J.A.; Berting, F.M.; Beyer, C.E.; Payne, G.A.; and Wu, S.L. 1993. Fuel Performance Annual Report for 1990. NUREG/CR-3950. Volume 8. Washington, D.C.: U.S. Nuclear Regulatory Commission. TIC: 245486

102068 Ravier, G.; Masuy, G.; and Willse, J.T. 1997. "Framatome and FCF Recent Operating Experience and Advanced Features to Increase Performance and Reliability." Proceedings of the 1997 International Topical Meeting on Light Water Reactor Fuel Performance, Portland, Oregon, March 2-6, 1997. Pages 31-36. La Grange Park, Illinois: American Nuclear Society. TIC: 232556.

107105 Roberts, W.L.; Campbell, T.J.; and Rapp, G.R., Jr. 1990. Encyclopedia of Minerals. $2^{\text {nd }}$. Edition. New York, New York: Van Nostrand Reinhold. TIC: 242976.

120630 Roddy, W.J.; Clairborne, H.C.; Ashline, R.C.; Johnson, P.J.; and Rhyme, B.T. 1985. Physical and Decay Characteristics of Commercial LWR Spent Fuel. ORNL/TM9591/V1. Oak Ridge, Tennessee: Oak Ridge National laboratory. ACC:

NNA.19891016.0145

135910 S. Cohen \& Associates 1999. Effectiveness of Fuel Rod Cladding as an Engineered Barrier in the Yucca Mountain Repository. McLean, Virginia: S. Cohen \& Associates. TIC: 246541.

102072 Sanders, T.L.; Seager, K.D.; Rashid, Y.R.; Barrett, P.R.; Malinauskas, A.P.; Einziger, R.E.; Jordan, H.; Duffey, T.A.; Sutherland, S.H.; and Reardon, P.C. 1992. A Method for Determining the Spent-Fuel Contribution to Transport Cask Containment Requirements. SAND90-2406. Albuquerque, New Mexico: Sandia National Laboratories. ACC: MOV.19960802.0116.

102074 Sasaki, S. and Kuwabara, S. 1997. "Utility Perspective on Commercial Light-Water Reactor Fuel in Japan." Proceedings of the 1997 International Topical Meeting on Light Water Reactor Fuel Performance, Portland, Oregon, March 2-6, 1997. Pages 11-20. La Grange Park, Illinois: American Nuclear Society. TIC: 232556.

160787 Siegmann, E. and Devonec, E. 2002. "Sensitivity Studies of the Effect of Cladding Degradation on TSPA Results." Scientific Basis for Nuclear Waste Management XXV, Symposium held November 26-29, 2001, Boston, Massachusetts. McGrail, B.P. and Cragnolino, G.A., eds. 713, 689-696. Warrendale, Pennsylvania: Materials Research Society. TIC: 248663. 
104724 Wilmot, E.L. 1981. Transportation Accident Scenarios for Commercial Spent Fuel. SAND80-2124. Albuquerque, New Mexico: Sandia National Laboratories.

ACC: HQO.19871023.0215.

102147 Wilson, C.N. 1985. Results from NNWSI Series 1 Spent Fuel Leach Tests. HEDLTME 84-30. Richland, Washington: Hanford Engineering Development Laboratory. ACC: HQS.19880517.2579.

102150 Wilson, C.N. 1987. Results from Cycles 1 and 2 of NNWSI Series 2 Spent Fuel Dissolution Tests. HEDL-TME 85-22. Richland, Washington: Hanford Engineering Development Laboratory. ACC: HQS.19880517.2581.

100793 Wilson, C.N. 1990. Results from NNWSI Series 3 Spent Fuel Dissolution Tests. PNL7170. Richland, Washington: Pacific Northwest Laboratory.

ACC: NNA.19900329.0142.

102158 Witte, M.C.; Chun, R.C.; and Schwartz, M.W. 1989. "Dynamic Impact Effects on Spent Fuel Assemblies." 9th International Symposium on the Packaging and Transportation of Radioactive Materials, Washington, D.C., June 11-16, 1989. 1, 186-194. Oak Ridge, Tennessee: Oak Ridge National Laboratory. TIC: 240741.

\subsection{CODES, STANDARDS, REGULATIONS AND PROCEDURES}

15660510 CFR Part 63. Energy: Disposal of High-Level Radioactive Wastes in a Geologic Repository at Yucca Mountain, Nevada. Readily available.

AP-2.22Q, Rev. 1, ICN 1. Classification Analyses and Maintenance of the Q-List. Washington, D.C.: U.S. Department of Energy, Office of Civilian Radioactive Waste Management. ACC: DOC.20040714.0002.

AP-SIII.3Q, Rev. 2, ICN 1. Submittal and Incorporation of Data to the Technical Data Management System. Washington, D.C.: U.S. Department of Energy, Office of Civilian Radioactive Waste Management. ACC: DOC.20040226.0001.

105725 ASTM C 1174-97. 1998. Standard Practice for Prediction of the Long-Term Behavior of Materials, Including Waste Forms, Used in Engineered Barrier Systems (EBS) for Geological Disposal of High-Level Radioactive Waste. West Conshohocken, Pennsylvania: American Society for Testing and Materials. TIC: 246015.

LP-2.14Q-BSC, Rev. 0, ICN 0. Document Review. Washington, D.C.: U.S. Department of Energy, Office of Civilian Radioactive Waste Management. ACC: DOC.20050113.0007.

LP-2.29Q-BSC, Rev. 0, ICN 0. Planning for Science Activities. Washington, D.C.: U.S. Department of Energy, Office of Civilian Radioactive Waste Management. ACC: DOC.20050114.0001. 
LP-3.15Q-BSC, Rev. 0, ICN 0. Managing Technical Product Inputs. Washington, D.C.: U.S. Department of Energy, Office of Civilian Radioactive Waste Management. ACC: DOC.20050113.0002.

LP-SI.11Q-BSC, Rev. 0, ICN 1. Software Management. Washington, D.C.: U.S. Department of Energy, Office of Civilian Radioactive Waste Management.

ACC: DOC.20041005.0008.

LP-SIII.9Q-BSC, Rev. 0, ICN 0, Scientific Analyses, Washington, D.C.: U.S. Department of Energy, Office of Civilian Radioactive Waste Management. ACC: DOC.20050203.0010.

\subsection{SOURCE DATA, LISTED BY DATA TRACKING NUMBER}

163089 LL010902212241.026. CSNF Alteration Phase Porosity Estimates. Submittal date: $09 / 21 / 2001$.

170760 MO0407SEPFEPLA.000. LA FEP List. Submittal Date 08/20/2004

\subsection{OUTPUT DATA, LISTED BY DATA TRACKING NUMBER}

MO0411SPACLDDG.003. TSPA-LA Parameters from Cladding Degradation Summary and Abstraction for LA. Submittal Date: December 3, 2004. 